\title{
Subsurface Geology of the A and M Areas of the Savannah River Plant, Aiken, South Carolina(U)
}

by

D. Jackson (Contact)

E. I. du Pont de Nemours and Company

Savannah River Site

Aiken, South Carolina 29808

W. C. Fallaw

K. A. Sargent

DOE Contract No $\lambda E-A Q 09-76$ SR $0000 \%$

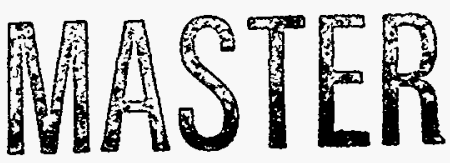

This paper was prepared in connection with work done under the above contract number with the U.S. . Department of Energy. By acceptance of this paper, the publisher and/or recipient acknowledges the U.S. Government's right to retain a nonexclusive, royalty-free license in and to any copyright covering this paper, along with the right to reproduce and to authorize others to reproduce all or part of the copyrighted paper. 


\section{DISCLAIMER}

This report was prepared as an account of work sponsored by an agency of the United States Government. Neither the United States Government nor any agency thereof, nor any of their employees, makes any warranty, express or implied, or assumes any legal liability or responsibility for the accuracy, completeness, or usefiulness of any information, apparatus, product, or process disclosed, or represents that its use would not infringe privately owned rights. Reference herein to any specific commercial product, process, or service by trade name, trademark, manufacturer, or otherwise does not necessarily constitute or imply its endorsement. recommendation, or favoring by the United States Government or any agency thereof. The views and opinions of authors expressed herein do not necessarily state or reflect those of the United States Governinent or any agency thereof.

This report has been reproduced directly from the best available copy.

Available to DOE and DOE contractors from the Office of Scientific and Technical Information, P.O.Box 62, Oak Ridge, TN 37831; prices available from (615) 57.6-8401.

Available to the public from the. National Technical-Information Service, U.S. Department of Commerce, 5285 Port Royal Road, Springfield, VA 22161. 


\section{DISCLAIMIER}

Portions of this document may be illegible in electronic image products. Images are produced from the best available original document. 
SUBSURFACE GEOLOGY OF THE A AND M AREAS

AT THE SAVANNAH RIVER PLANT, AIKEN, SOUTH CAROLINA

\author{
by \\ W.C. Fallaw \\ and \\ K.A. Sargent \\ June 1986
}

Submitted in partial fulfillment

of Contract AX 715063

for

E.I. duPont de Nemours \& Company

- Savannah River Plant...

Aiken, South Carolina 29808

Geological Consulting Services

Rt. 7, 12 Kensington Road

Greenville, South Carolina 29609 


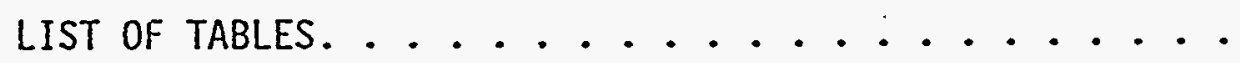

INTRODUCTION. .................

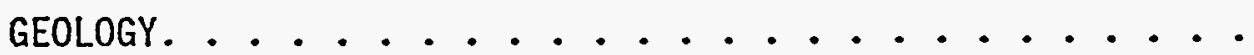

REFERENCES CITED. ...............

LITHOLOGIC AND GEOPHYSICAL LOGS. . . . . . . . .

Appendix 


\section{LIST OF ILLUSTRATIONS}

PAGE

Figure 1. Location map of borings used in geologic study.

Figure 2. Structure contour map of top surface, Black

Creek Formation. On all maps, wells without

Tetter designations are MSB wells.

Figure 3. Structure contour map of top surface, Ellenton

Formation. Because the higher units of the

Ellenton are missing in places, the surface is

in 4 of the 5 Ellenton units.

Figure 4. Isopach map of the entire Ellenton Formation.

Figure 5. Structure contour of top surface, Tower Elienton-

clay.

Figure 6. Isopach map, Tower Ellenton clay.

Figure 7. Structure contour map of top surface, lower

Ellenton sand.

Figure 8. Isopach map, Tower Ellenton sand.

Figure 9. Structure contour map of top surface, middle Ellenton clay.

Figure 10. Isopach map, middle Ellenton clay.

Figure 11. Structure contour map of top surface, upper

Ellenton sand. 
Figure 12. Isopach map, upper Ellenton sand.

Figure 13. Structure contour map of top surface, upper Ellenton clay.

Figure 14. Isopach map, upper ElTenton clay.

Figure 15. Structure contour map of top surface, lower

Congaree sand. Because the clayey zone of the

Congaree is missng in the south, the Congaree

Formation is not subdivided there.

Figure 16. Isopach map, Tower Congaree sand.

Figure 17. Structure contour map of top surface, Congaree clayey zone.

Figure 18. Isopach map, Congaree clayey zone.

Figure 19. Structure contour map of top surface, Congaree Formation.

Figure 20. Isopach map, upper Congaree sand. Because, the clayey zone is missing in the south, the entire thickness of the Congaree Formation is mapped there.

Figure 21. Structure contour map of top surface, McBean Formation.

Figure 22. Silt and clay percentage map, McBean Formation. 
Figure 23. Isopach map, McBean Formation.

Figure 24. Structure contour map of top surface, Dry Branch Formation (1awer unit of the Barnwell Group).

Figure 25. Isopach map, Dry Branch Formation.

Figure 26. Structure contour map of top surface, Tobacco Road Formation (upper unit of the Barnwell Group).

Figure 27. Isopach map, Tobacco Road Formation.

Figure 28. Isopach map, Upland unit. Only ground elevations at wells were used in making the map. The existing topography is the top surface of the Upland unit except in the south, where the Tobacco Road and Dry Branch Formations are exposed on the surface.

Figure 29. Map showing lines of cross-section (Figs. 30-34):

Figure 30-34. Cross-sections. Dips are not as steep as shown because of a 12-to-1 vertical exaggeration of the sections. The configuration between wells is based on structure contour maps of the stratigraphic units. Rock types are generalized, with no details shown. 


\section{LIST OF TABLES}

Table

Page

1 Data Used in Geologic Study

6

2 Elevations of Stratigraphic Units

7,8

3 Ellenton Size Analysis Date

24

4 Lower Congaree Size Anaiysis Data

24

5 Upper Congaree Size Analysis Data

6 Average Clay and Silt Content from Visual Analysis

7 McBean Size Analysis Data. 


\section{INTRODUCTION}

A study of the subsurface geology of $A$ and $M$ areas at the Savannah River Plant was begun in the summer of 1984 with the establishing of a sedimentological Taboratory at Building 704-U. Here, core samples, recovered during the drilling of selected $A$ and $M$ area monitoring wells, we examined by trained geologists under the supervision of Dr. W.C. Fallaw. This project was continued during the summer of 1985 . The results of these studies were used, along with available borehole geophysics, to delineate the subsurface geology. This report is based on these investigations. The sedimentological data obtained are summarized by monitor well as a lithologic log and are presented along with the borehole geophysics in the Appendix.

The geological interpretation is presented in the form of structure contour maps, isopach maps, and cross-sections. The study is limited to existing data from $A$ and $M$ areas, and the interpretation may change as additional data become avaitable.

\section{GEOLOGY}

\section{STRATIGRAPHIC SECTION}

The Cretaceous and Cenozoic sediments of the Coastal Plain are approximately $700 \mathrm{ft}$ thick in $A$ and $M$ Area and regional dip is to the southeast (Siple, 1967; Colquhoun et. al., 1983). The sediments are mostly loose and partially indurated sands and clays, and they overlie Precambrian or Paleozoic metamorphic rocks of the Appalachian Province. Newark-type Triassic sediments occur between the Coastal Plain sediments and the Appalachian crystalline rocks in a part of the Savannah River Plant, but none are known in $A$ and $M$ 
areas. The cretaceous and Cenozoic deposits appear to have formed in fluvial, deltaic, and shallow marine environments.

Terminology used for the strata varies among the studies done in the SRP area. Among the more pertinent publications are Sloan (1908), Cooke (1936), Siple (1967), Nystrom and Willoughby (1982), Carter (1983), and Colquhoun et a1. (1983). The terminology of this report, shown below, is based on a review of these studies, and on the usage of DuPont employees concerned with subsurface stratigraphy. Further study may result in revision.

Upland unit
Barnwell Group Anconformity? unknown
Tobacco Road Formation
Dry Branch Formation

Unconformity

McBean Formation

Middle Eocene

Unconformity?

Congaree Formation

Middle Eocene

Unconformity

Ellenton Formation

Paleocene

Unconformity

Black Creek Formation

Late Cretaceous

Unconformity

Middendorf Formation

Late Cretaceous

METHODS

The core samples were acquired using either a split spoon or phosphate barrel sampler. The split spoon sampler retrieves a $17 / 8$ in-diameter core in runs up to 24 in long. The phosphate barrel sampler retrieves a $37 / 8$ indiameter core in runs up to $10 \mathrm{ft}$ in length but more commonly in unconsolidated sediments is restricted to less than $5 \mathrm{ft}$. Upon recovery, the cores were wrapped in aluminum foil or a polyvinyl plastic sheet and stored in core boxes marked to record the sampling interval and to distinguish top and bottom of 
the core samples. Storage boxes were normaliy of waxed corrugated cardboard construction but on occasion wood boxes were used. Long-term storage was effected in a locked building.

The cores were examined megascopically and with binocular microscopes, and these properties were recorded:

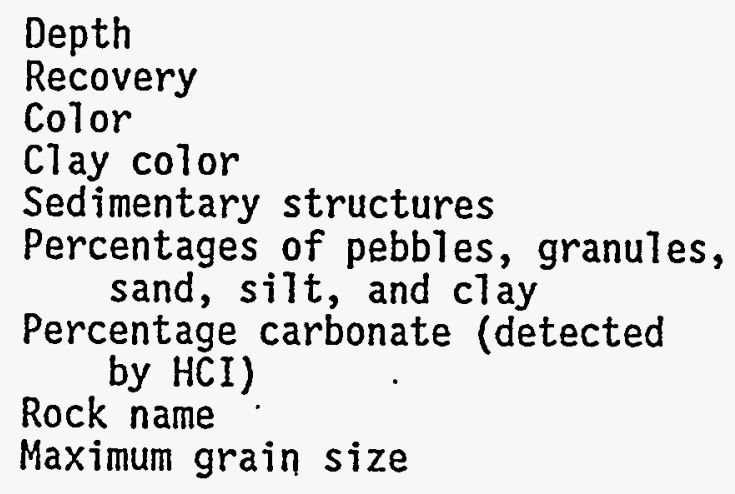

Grain sizes were estimated by comparing the core samples with sieved fractions of known size, and percentages were estimated by comparing the core samples with diagrams showing how various percentages would appear under the microscope (Terry and Chilingar, 1955). The Wentworth-Udden scale was used for grain sizes. This is shown below, and on the far right is shown the corresponding of scale terminology, o being the negative of the logarithm to the base 2 of the grain size diameter. The $\alpha$ units were used in parameters (Folk and Ward, 1956) of size frequency distributions for samples which had been size analyzed by sieve and hydrometer:

\begin{tabular}{lrr} 
Grain Size & Diameter in mm & Scale \\
\cline { 2 - 3 } Pebbles & 4 & -2 \\
Granules & $2-4$ & $-1--2$ \\
Very coarse sand & $1-2$ & $0--1$ \\
Coarse sand & $1 / 2-1$ & $1-0$ \\
Medium sand & $1 / 4-1 / 2$ & $2-1$ \\
Fine sand & $1 / 8-1 / 4$ & $3-2$ \\
Very fine sand & $1 / 16-1 / 8$ & $4-3$ \\
Silt & $1 / 256-1 / 16$ & $4-8$ \\
Clay & $1 / 256$ & \\
& $-3-$ &
\end{tabular}


In the formation descriptions, the average size fraction percentages and sorting are based on visual analysis. In the presentation of the results for the few samples which were sieved and analyzed by hydrometer, the sand percentage also includes granules and pebbles, these being present in only minute amounts in those samples.

Sorting, a measure of the degree to which all grains in a sample approach the same size, was estimated for sands according to this scale:
We11 sorted
Moderately sorted
Poorly soted
$90 \%$ of sample within 2 sand size classes
Very poorly sorted
$90 \%$ of sample within 3 sand size classes
$90 \%$ of sample within 4 sand size classes
$90 \%$ of sample within more than 4 size classes

In general, the core data were recorded at $2 \mathrm{ft}$.intervals, but where there was an obvious lithologic break wihin the interval, smaller intervals were recorded. Lithologic logs (see Appendix) on a scale of 1 in to $10 \mathrm{ft}$ were prepared from the coded data. Major features recorded on the logs are modal grain size, maximum grain size, pebble plus granule percentages, sorting, carbonate zones, dominant color, sedimentary structures, fossils, and content of muscovite, glauconite, lignite, and heavy minerals.

of the 47 borings used in the stratigraphic study, 33 were cored. Some borings were cored continuously and some were cored $2 \mathrm{ft}$ in every $5 \mathrm{ft}$ of depth. Figure 1 shows the locations of the borings and Table 1 shows the amount of data available. In making correlations and describing formation lithologies, great reliance was placed on 13 borings which were cored continuously at least throughthe Eocene section: ASB-8, MSB-10, -11, -12, -13, $-21,-29,-30,-31,-36,-40,-41$, and -42 . 


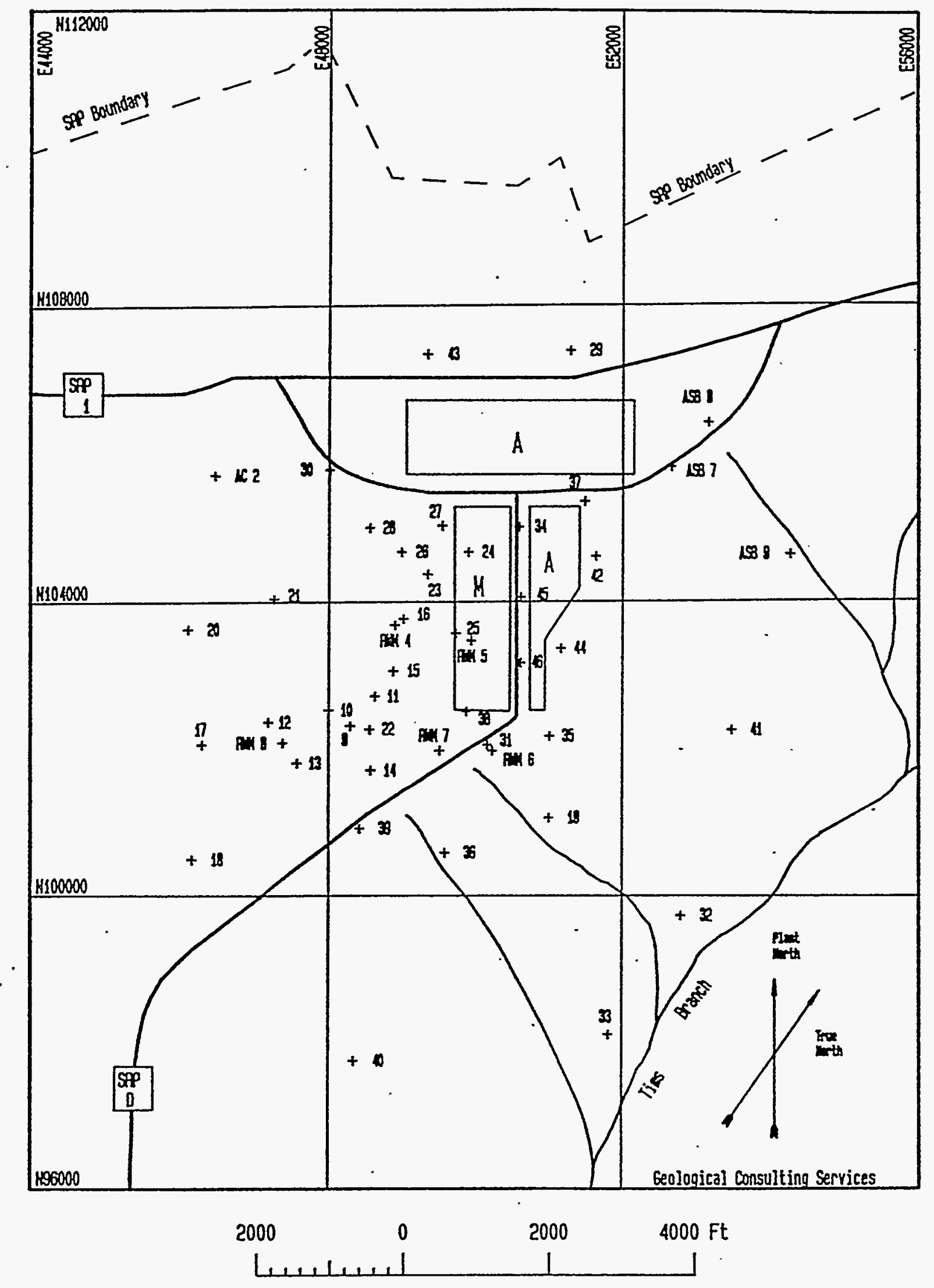

Figure 1. Location map of borings used in geologic study. 
Table 1. Data Used in Geologic study. Elevations relative to mean sea Tevel CORES GEOPHYSICAL LOGS

Elevations of Thickness of Core Elevations of Thickness

We11 Intervals Cored Interval Cored Spacing* Intervals Logged of Intervals

Cluster

AC2

ASB 7

ASB 8

$343-139$

$351-211$

$349-11$

ASB 9

306-216

MSB 9

$357-263$

MSB 70

353-104

MSB 11

363-123

$346-(-313)$

343-99

346-143

365-163

365-163

266-154

248-141

298-96

262-150

204

140

338

90

94.

249

240

MSB 13

MSB 14

MSB 17

MSB 18

MSB 19

MSB 20

MSB 21

MSB 22

$354-16$

357-155

MSB 23

MSB 24

MSB 25

MSB 26

MSB 27

MSB 28

MSB 29

370-54

379-127

365-113

359-156

374-171

252-151

$364-47$

253-27

246-12

659

244

203

202

202

112

107

202

112

338

202

316

252

252

203

203

101

MSB 30

MSB 31

MSB 32

MSB 33

MSB 34

MSB 35

MSB 36

MSB 37

MSB. 38

MSB-39

MSB 40

MSB 41

MSB 42

MSB 43

MSB 44

MSB 45

MSB 46

RWM 4

317

226

234

$387-(-279) \cdot \quad 660$

$340-38$

$382-260$

$321-9$

$323-18$

$376-36$

302

382

$2 / 5$

$\mathrm{ft}$

$\begin{array}{cc}\mathrm{ft} & \mathrm{ft} \\ 337-143 & 194 \\ 349-19 & 330\end{array}$

Continuous $\quad 349-19$

236

Continuous

Continuous

348-112

234

Continuous

$357-123$

647

Continuous

$2 / 5$

$2 / 5$

$2 / 5$

$2 / 5$

$2 / 5$

$2 / 5$

$2 / 5$

Continuous

$2 / 5$

$2 / 5$

$2 / 5$

$2 / 5$

$2 / 5$

$2 / 5$

$2 / 5$

$338-(-309)$

$337-98$

340-147

239

359-165

193

359-167

194

192

$350-156$

194

$332-138$

194

292-98

194

194

346-152

344

326

Continuous

Continuous

Continuous

$372-60$

312

$364-52$

312

$348-33$

315

247-40 207

$257-7$

$375-(-279)$

244

$2 / 5$

Continuous

$348-34$

654

214

$338-40 \quad$. 298

Cuttings

$374-(-4)$

378

$352-32$

320

$338-40$

298

312

305

Continuous

$319-23$

296

Continuous

$323-12$

311

$371-25$

346

$355-41$

314

$\begin{array}{ll}370-118 & 252 \\ 374-120 & 254\end{array}$

368-122 246

$360-126 \quad 234$

$361-103 \quad 258$

$347-138 \quad 209$

$345-141 \quad 204$

RWM 6

RWM 7

346- 700

246

* 2/5 indicates well was cored $2 \mathrm{ft}$ of every $5 \mathrm{ft}$ 
Table 2. Elevations of Tops of Stratigraphic Units. Elevations given are relative to mean sea level.

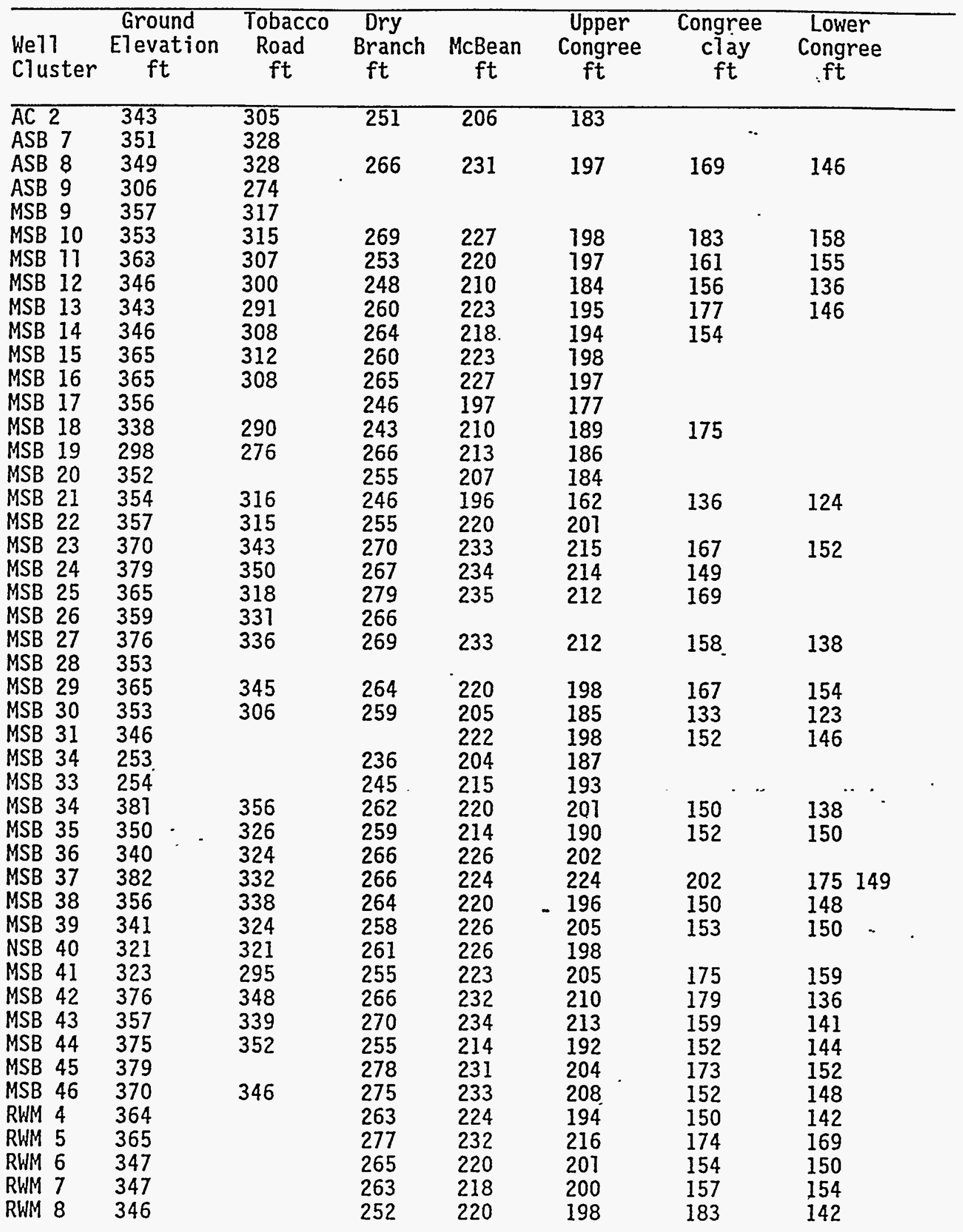


Tab7e 2. (continued)

\begin{tabular}{|c|c|c|c|c|c|c|}
\hline $\begin{array}{l}\text { Well } \\
\text { Cluster }\end{array}$ & $\begin{array}{l}\text { Upper } \\
\text { clay } \\
\text { ft }\end{array}$ & $\begin{array}{l}\text { Upper } \\
\text { sand } \\
\text { ft }\end{array}$ & $\begin{array}{l}\text { ELLENTON } \\
\text { Middle } \\
\text { clay } \\
\text { ft }\end{array}$ & $\begin{array}{c}\text { Lower } \\
\text { sand } \\
\mathrm{ft}\end{array}$ & $\begin{array}{l}\text { Lower } \\
\text { clay } \\
\mathrm{ft}\end{array}$ & BLACK CREEK \\
\hline \multicolumn{7}{|l|}{$\begin{array}{ll}\mathrm{AC} & 2 \\
\mathrm{ASB} & 7\end{array}$} \\
\hline ASB 8 & & & 102 & 95 & 71 & 55 \\
\hline ASB 9 & & & & & & \\
\hline \multicolumn{7}{|l|}{ MSB 9} \\
\hline MSB 10 & & & 147 & 138 & 118 & \\
\hline MSB 11 & & & 148 & 143 & 129 & \\
\hline MSB 12 & 112 & 110 & 106 & 101 & 73 & 34 \\
\hline $\begin{array}{l}\text { MSB } \\
\text { MSB } \\
\text { MS }\end{array}$ & & & & 109 & & \\
\hline MSB 15 & & & & & & \\
\hline $\begin{array}{ll}\text { MSB } & 16 \\
\text { MSB } & 17\end{array}$ & & & & & & \\
\hline \multicolumn{7}{|l|}{ MSB 18} \\
\hline $\begin{array}{l}\text { MSB } 19 \\
\text { MSB } 20\end{array}$ & & & 133 & 130 & 110 & \\
\hline \multicolumn{7}{|c|}{$\begin{array}{lll}\text { MSB } & 20 & \\
\text { MSB } & 21 & 114\end{array}$} \\
\hline \multirow{2}{*}{\multicolumn{7}{|c|}{$\begin{array}{l}\text { MSB } 23 \\
\text { MSB } 24\end{array}$}} \\
\hline & & $1<0$ & $16 C$ & 111 & J & 00 \\
\hline \multicolumn{7}{|l|}{$\begin{array}{l}\text { MSB } 25 \\
\text { MSB } 26\end{array}$} \\
\hline \multicolumn{7}{|l|}{ MSB 27} \\
\hline MSB 28 & & & 133 & 129 & 113 & 101 \\
\hline MSB 30 & & & 117 & 113 & 93 & 37 \\
\hline MSB 31 & & & 140 & 128 & 114 & 68 \\
\hline MSB 32 & 118 & 114 & 112 & 110 & 97 & 53 \\
\hline MSB 33 & 147 & 141 & 132 & 113 & 82 & 55 \\
\hline \multirow{2}{*}{\multicolumn{6}{|c|}{ MSB 34}} & \\
\hline & & & 140 & 134 & 117 & 67 \\
\hline \multicolumn{7}{|l|}{$\begin{array}{l}\text { MSB } 36 \\
\text { MSB } 37\end{array}$} \\
\hline MSB 37 & & & 130 & 123 & 104 & 87 \\
\hline \multicolumn{7}{|l|}{ MSB 38} \\
\hline MSB 39 & 140 & 137 & 132 & 119 & 101 & 86 \\
\hline \multirow{2}{*}{\multicolumn{7}{|c|}{$\begin{array}{l}\text { MSB } 40 \\
\text { MSB } 41\end{array}$}} \\
\hline & 126 & 125 & 123 & 121 & 81 & 62 \\
\hline \multirow{2}{*}{\multicolumn{7}{|c|}{$\begin{array}{l}\text { MSB } 42 \\
\text { MSB } 43\end{array}$}} \\
\hline & & & 128 & 126 & 108 & 72 \\
\hline \multicolumn{7}{|l|}{$\begin{array}{l}\text { MSB } \\
\text { MSB } \\
\text { MS5 }\end{array}$} \\
\hline MSB 45 & & & 134 & & & \\
\hline MSB 46 & & & 144 & 139 & 120 & \\
\hline \multicolumn{7}{|l|}{$\begin{array}{l}\text { RWM } \\
\text { RWM } \\
\text { RW } \\
\text { RWM } 6 \\
\text { RWM } 7\end{array}$} \\
\hline $\begin{array}{l}\text { RWM } 6 \\
\text { RWM } 7\end{array}$ & & & & & & \\
\hline RWM 8 & 119 & 117 & 112 & & & \\
\hline
\end{tabular}


FORMATION DESCRIPTIONS

Middendorf Formation

The two deepest borings in $M$ area, MSB-12 and MS-34, cored into the Middendorf but did not drill through it. MSB-12, the deeper of the two, reached an elevation of -313 . The top of the formation was picked at the top of a thick clay at -113 in \#34 and -118 in \#12. The assignment of this clay to the Middendorf rather than the Black Creek is arbitrary.

The Middendorf consists mostly of medium- and coarse-grained, moderately and well-sorted quartz sand, averaging $17 \%$ silt and clay. Pebbly layers are common. Muscovite is common in some places, but not as abundant as in the overlying Black Creek Formation. Tan is the most common color, with gray, white, purple, orange, and yellow occurring. In addition to the clay at the top of the unit, clay and silt layers are interbedded with the sand. Roughiy $20 \%$ of the sand section underlying the upper clay is composed of silt and clay beds. These fine-grained beds appear to be discontinuous, but the thick upper clay seems to be extensive within SRP. The upper clay is $38 \mathrm{ft}$ thick in MSB34. In MSB-12, the upper clay is divided into two parts by a $14 \mathrm{ft}$ thick Tayer of sand. The upper layer of clay is $9 \mathrm{ft}$ and the lower $10 \mathrm{ft}$ thick.

The depositional units appear to be discontinuous, except perhaps the top clay. The irregular bedding, variation in sorting, and clay balls suggest that the Middendorf was deposited in fluvial environments. Most of the sands are probably point bar and channel deposits. The thin clays and silts were probably formed in overbank environments.

Black Creek Formation

Thirteen. $A$ and $M$ borings are cored into the Black Creek Formation and seven others were logged geophysically. OnTy MSB-12 and MSB-34 drilled through it. The formation is $152 \mathrm{ft}$ thick in \#12 and $180 \mathrm{ft}$ thick in \#34. The upper contact is picked at the bottom of a thick clay immediateiy below 
the poorly sorted, dark sands of the Ellenton Formation. The boundary is distinct on both lithologic and geophysical logs. Figure 2 is a structure contour map of the top surface of the BTack Creek Formation. The lower contact is picked at the upper surface of the thick clay at the top of the Middendorf. Both contacts are probably unconformable (Colquhoun et al., 1983).

Most of the Black Creek consists of medium and coarse sands. Sorting is quite variable, ranging from well sorted to very poorly sorted, with the former being more common. Pebbly beds occur throughout, and clay balls are common. The sands are generally micaceous, more so than in the Middendorf, and feidspar and pyrite are rare. Tan, white, and yellow sands are most common, and the top of the sand is black in several borings, perhaps stained by the overlying Ellenton in some cases. Sands average 18\% silt and clay. The upper part of the sand is massive, but clay beds occur in the lower part in the two deep borings. About $5 \%$ of the section is composed of silt and clay beds. Within the upper $30 \mathrm{ft}$, a zone penetrated by 10 continuously cored borings, $22 \%$ of the sediment is clay and silt. The deposits are similar to those of the Middendorf and appear to be fluvial.

\section{Ellenton Formation}

Parts of the Paleocene Ellenton Formation are dark gray or black, poorly sorted, fine to coarse, clayey, silty sand and dark, kaolinitic clay and clayey silt. Muscovite, feldspar, iron sulfide and lignite are common in these sediments. In other places in the $A$ and $M$ areas the Ellenton sands and clays are tan, purple, or orange, are better sorted, and tend to lack the sulfide and lignite found in the dark sediments. Both dark and light deposits contain pebbly zones. Some borings have both dark and light sections. A . crude pattern seems to exist, however. Light deposits tend to occur in the northeastern part of the study area which is structurally low, and near a 


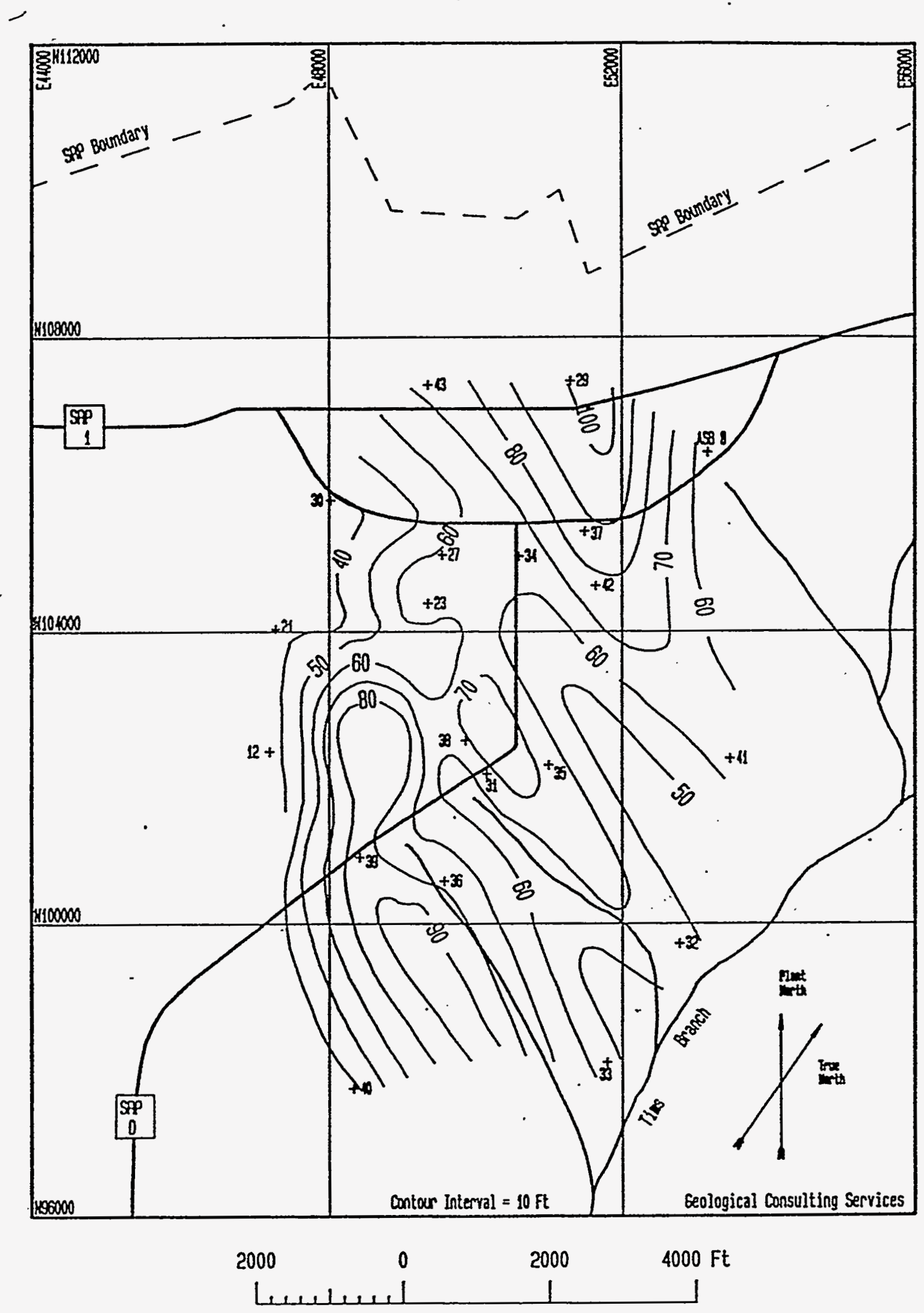

Figure 2. Structure contour map of top surface, Black Creek Formation 
structural high which is located near MSB-11. It is possible that some of the lighter sediments were deposited in post-Ellenton time. Their muscovite and feldspar content is more similar to that of the typical Ellenton than to the Eocene sands, and the shape of the modal size curves is similar to that of the dark Ellenton. The light color may have developed secondarily by leaching and oxidation of sulfides, and lignite. For the Ellenton as a whole, clay and silt beds make up $59 \%$ of the unit, and $62 \%$ of all sediments are clay and silt. Table 3 gives the results of size analysis of some of the lighter, better sorted sands. The lower boundary of the Ellenton is picked at the contact between a thick clay and the thick Black Creek sand section. The upper contact is picked at the base of a thick Eocene sand section which is usually a lighter color and much better sorted than the Ellenton. An indurated iron oxide layer marks this boundary in several borings. In Figure 3 is a structure contour map of the top. surface of the Ellenton.

Thickness of the Ellenton in $A$ and $M$ area borings is from 32 to $95 \mathrm{ft}$. (See Figure 4). The upper part of the Ellenton is absent in some borings which are generally in a zone trending north-south through $A$ and $M$ areas. (See Figures 11 and 13) This zone corresponds crudely to structurally high trends, but some borings with a missing section occur off structure. In a complete section, the Ellenton consists of five units. These are, from bottom to top: a thick clay, a thick sand, a medium-thickness clay, a thin sand, and a thin clay. The clay at the bottom, of the formation is from 10 to $56 \mathrm{ft}$ thick, and generally thins toward structural highs. (See Figures 5 and 6). In most borings, the clay is gray, greenish gray, or black. In other borings oxidized colors are common, such as red, purple, orange, and yellow. Some borings which have dark clay also have an oxidized zone at the top, and some borings have interbedded light and dark layers. 


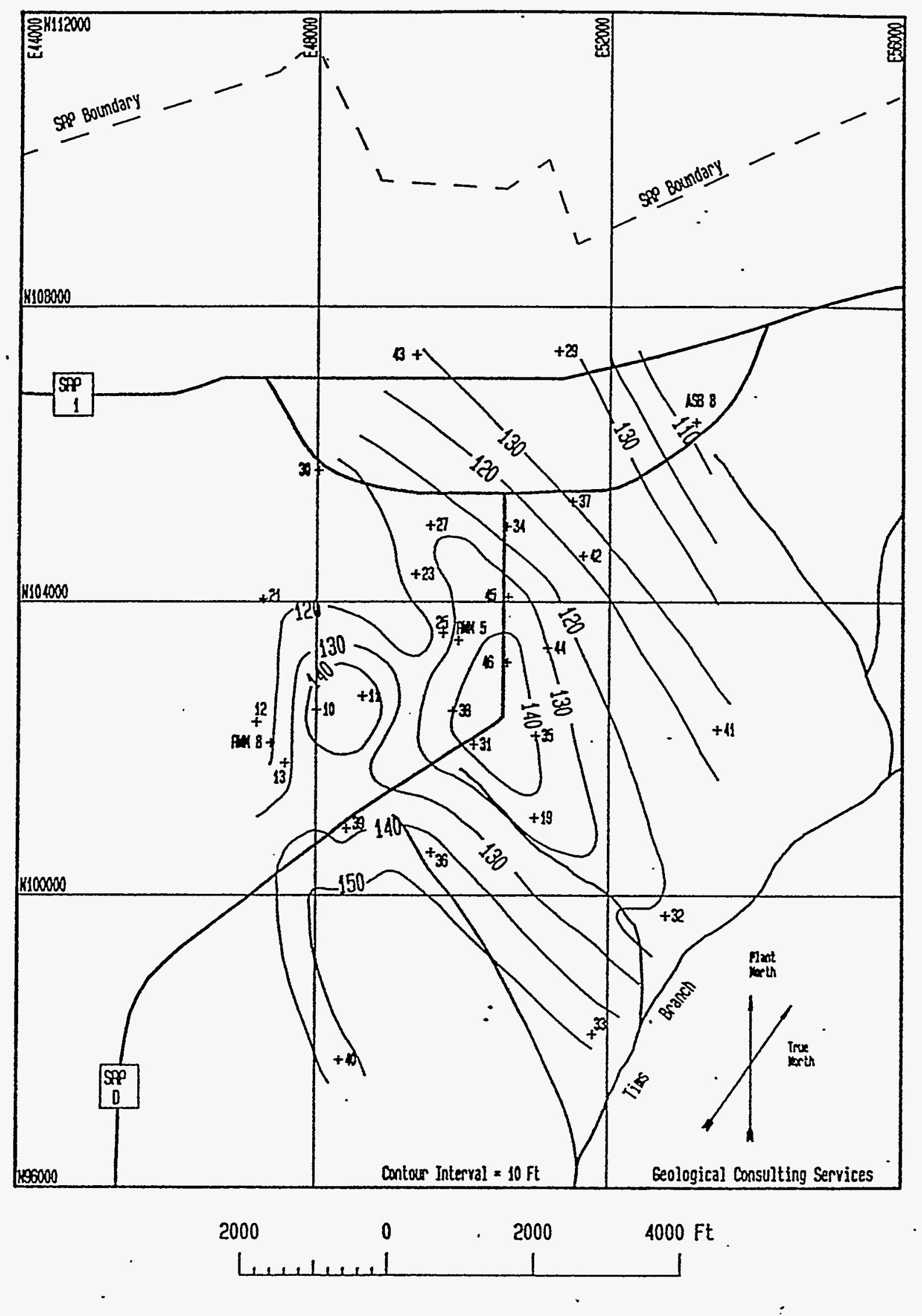

Figure 3. Structure contour of top surface, Ellenton Formation. 


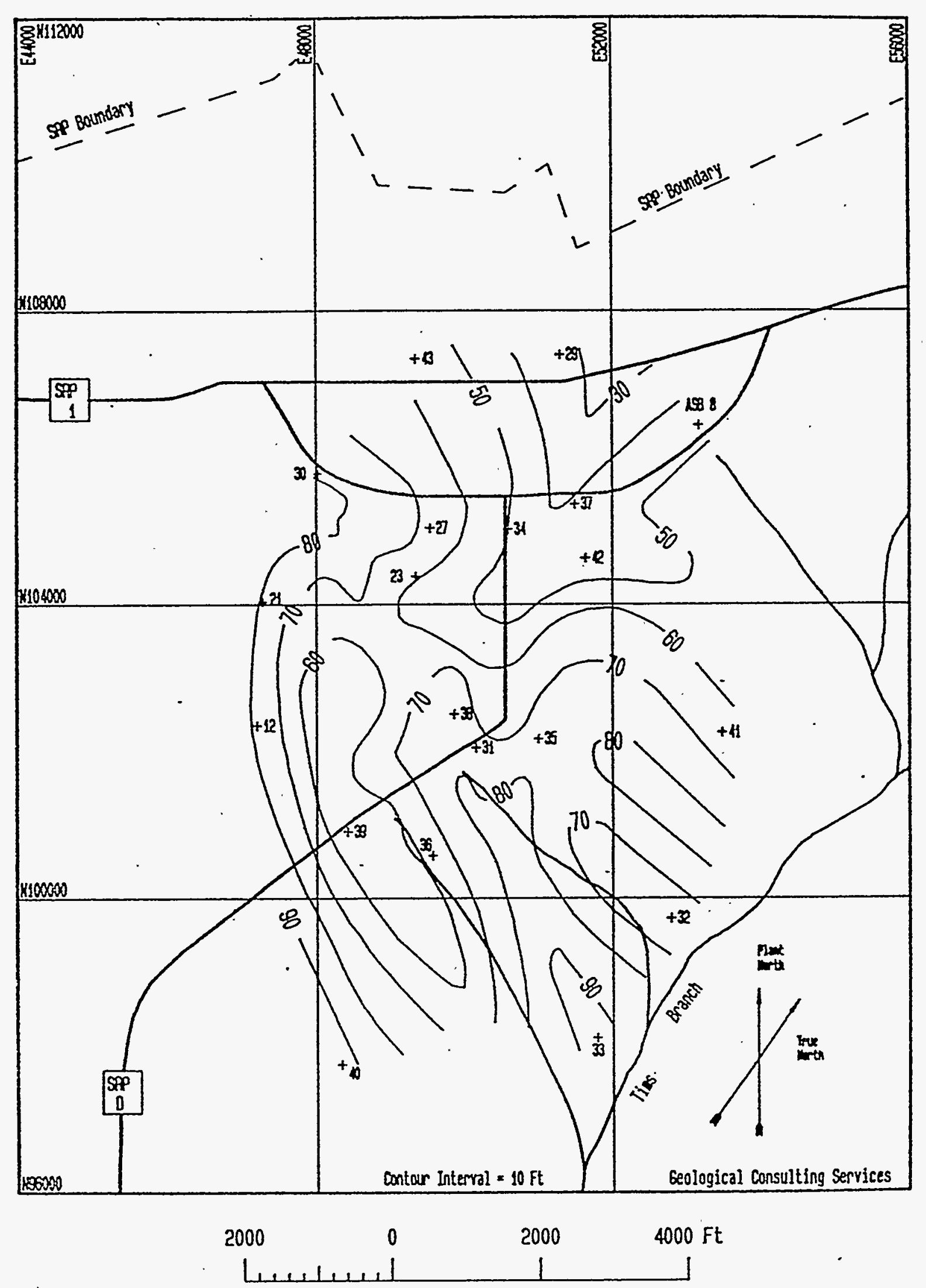

Figure 4. Isopach map of the entire Ellenton Formation.

$-18-$ 


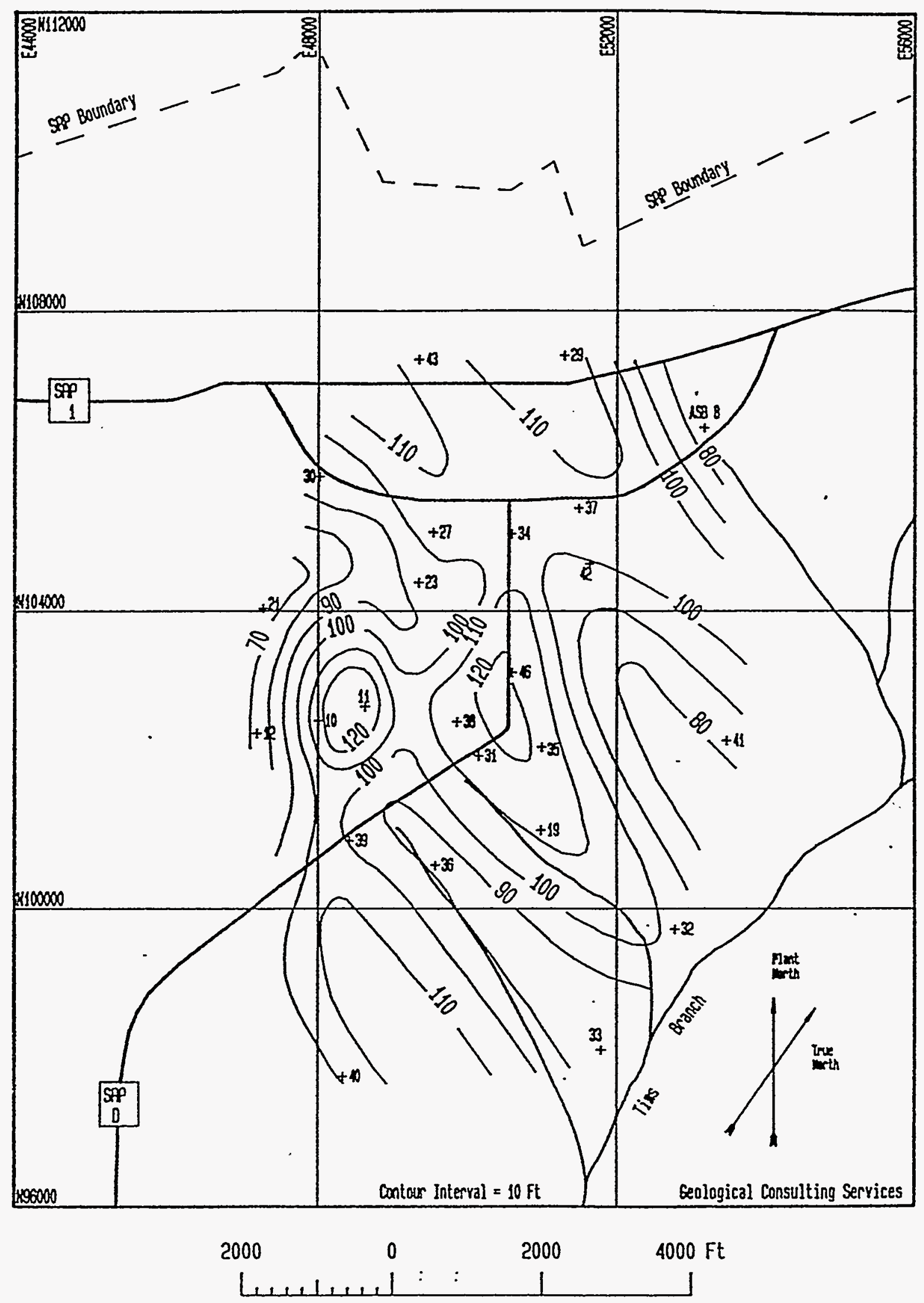

Figure 5. Structure contour map of top surface, lower Ellenton clay. 


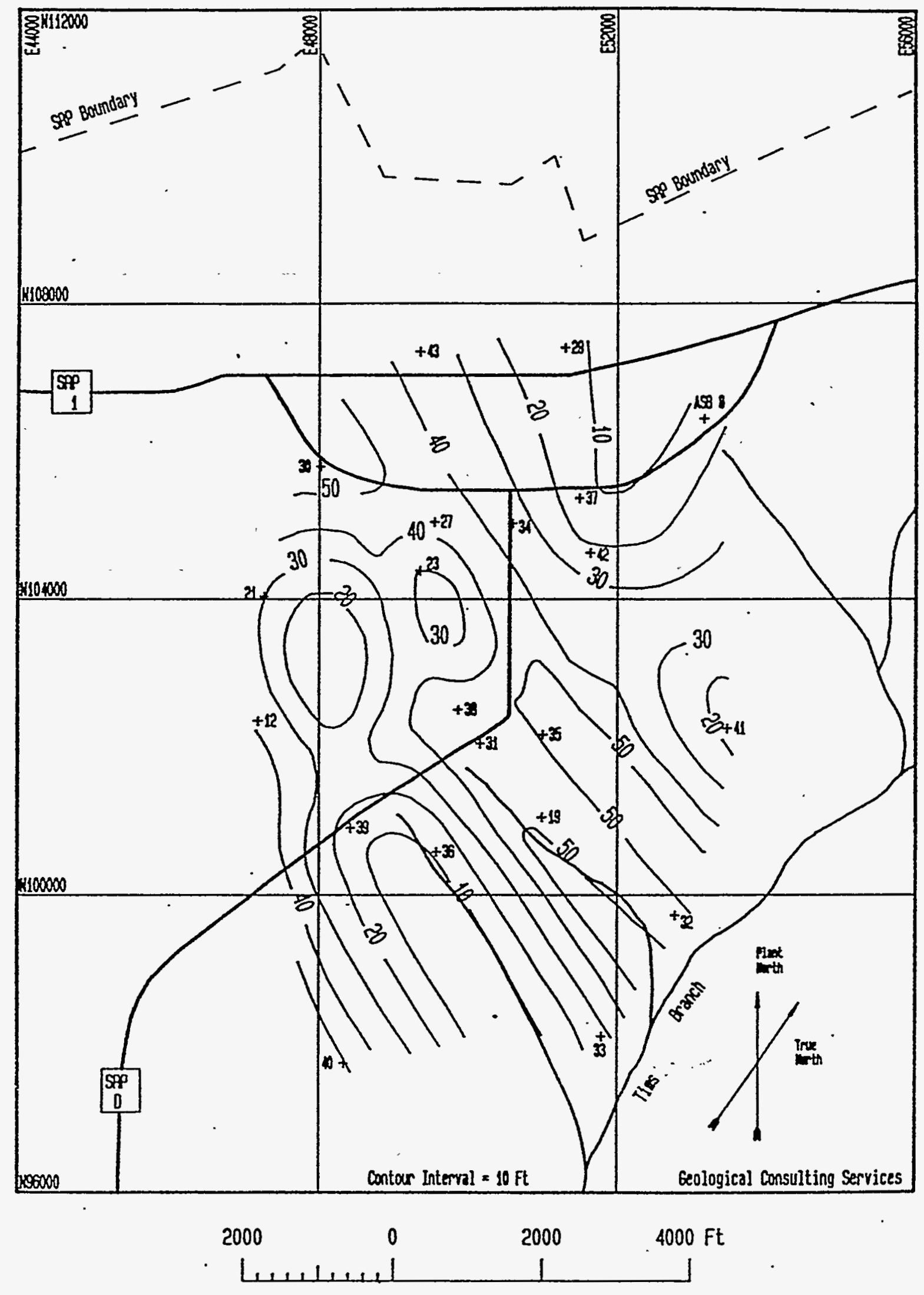

Figure 6. Isopach map, lower Ellenton clay. 
- A sandy zone from 2 to $8 \mathrm{ft}$ thick was encountered in a few borings about 15 to $20 \mathrm{ft}$ above the base of the clay. Iron sulfide occurs in some borings, lignite in a few, and fissility was observed in a small section of core in one boring. In MSB-36, a section of core from the base of the clay layer was seen to expand in diameter by perhaps $25 \%$ when removed from the core barre]. X-ray analysis revealed only kaolinite and quartz in this material. Pebbles occur in parts of the clay, but in general the largest particle size is medium or coarse sand.

Dinoflagellates and pollen from the lower clay yielded Eocene(?) dates from MSB-12 and MSB-34, Paleocene(?) in MSB-42, and Early Paleocene in MSB-36. Steete (1985) assigned this clay in $M$ area to the Paleocene, using a gamma ray kick at the base as a Cretaceous-Paleocene Contact.

The lower Ellenton sand is generally coarse to very coarse, micaceous, feldspathic, and poorly sorted, although light-colored, cleaner sands occur in some borings. Average size fractions of this sand are $77 \%$ sand size and larger, and $23 \%$ silt and clay. Several clay beds, 1 to $2 \mathrm{ft}$. thick, are interbedded with the sand in most borings. The sand is from 10 to $40 \mathrm{ft}$ thick and thins toward structural highs (See Figures 7 and 8 ).

The middle clay attains a thickness of more than $20 \mathrm{ft}$ off structure and tends to thin toward highs (See Figures 9 and 10) It appears to be missing in MSB-34, allowing the lower Ellenton sand to be in contact with Eocene sand. Dinoflagel7ates and pollen indicate an Eocene age for the clay in MSB-21.

The upper Ellenton sand is up to $9 \mathrm{ft}$ thick and tends to be missing in some borings (See Figures 11 and 12). It is medium and fine grained, silty and clayey, poorly sorted, and micaceous. Size fractions average $66 \%$ sand size and 1 arger, and $34 \%$ silt and clay. Dinoflagellate and pollen dates from this unit are Early Paleocene in MSB-23 and MSB-36. 


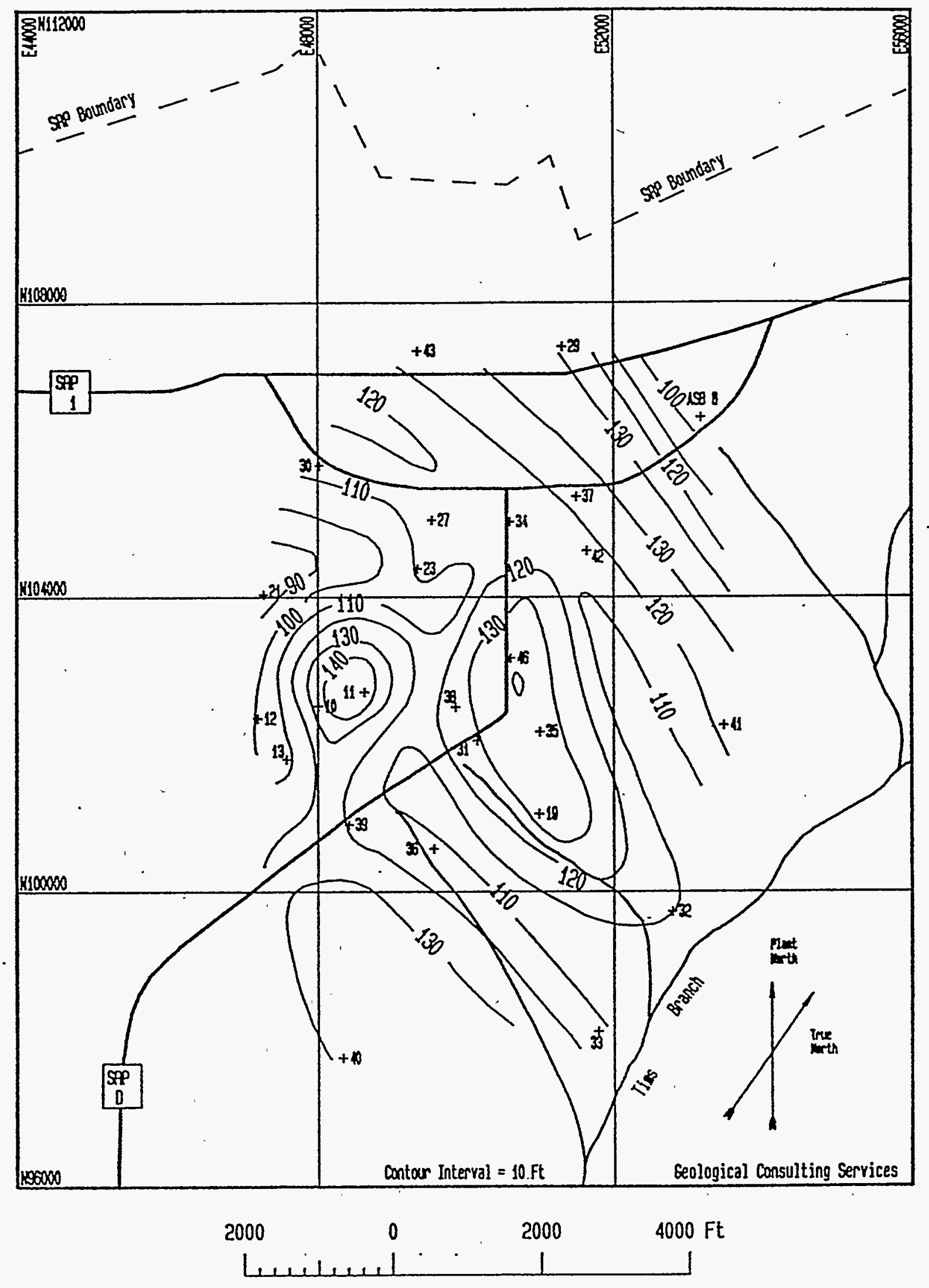

Figure 7. Structure contour map of top surface, lower Ellenton sand. 


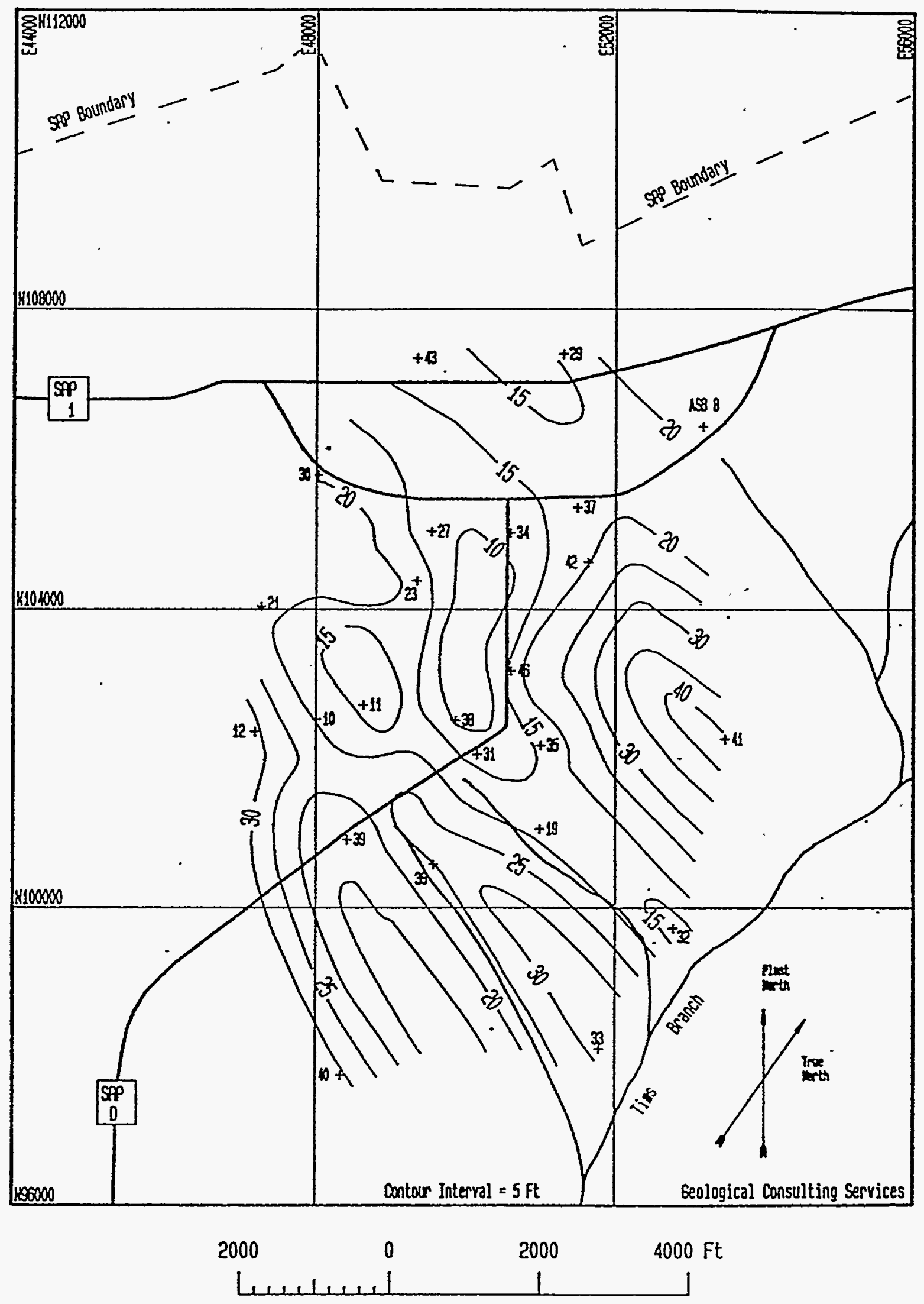

Figure 8. Isopach map, lower Ellenton sand. 


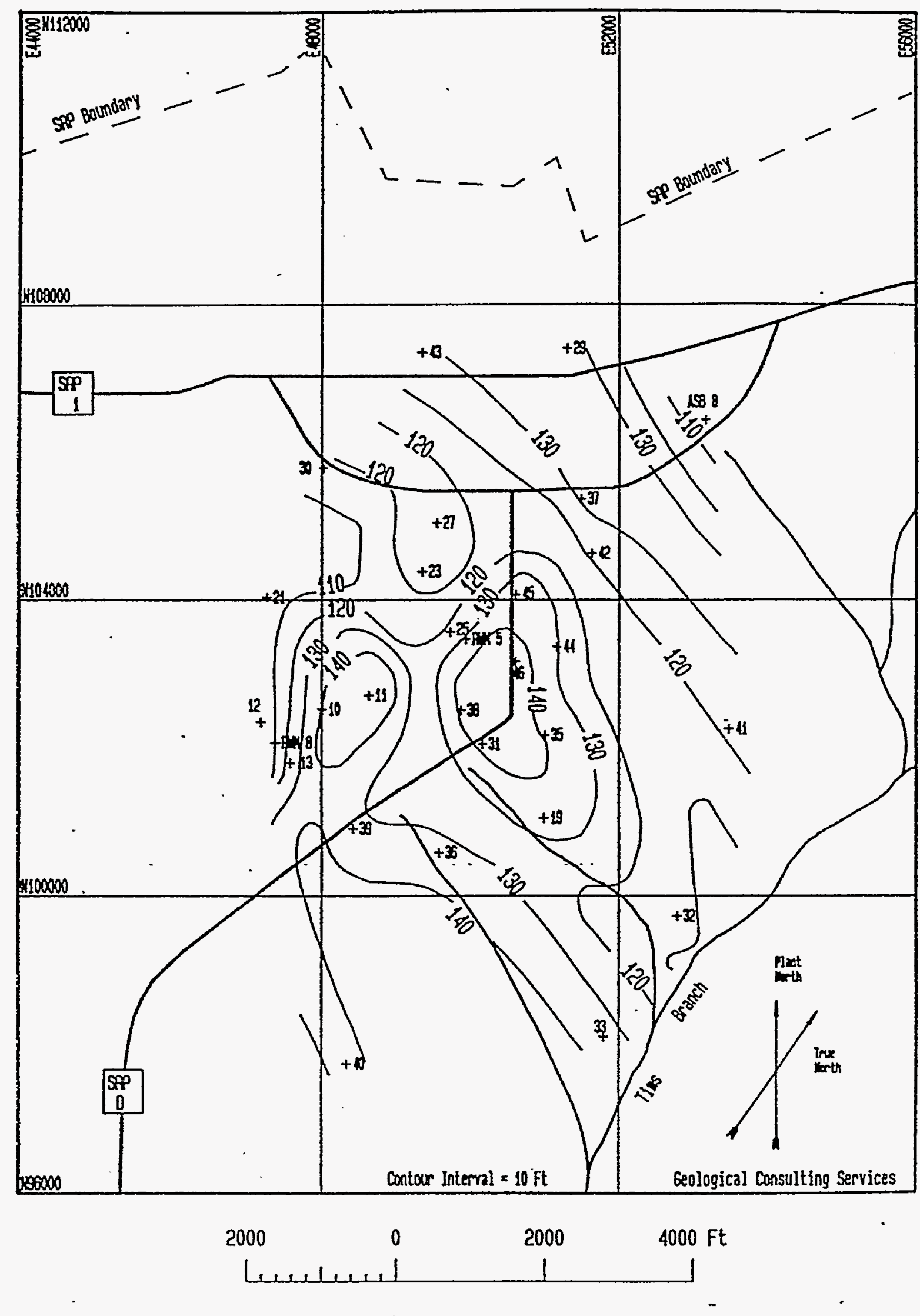

Fig. 9. Structure contour map of top surface, middle Ellenton clay. 


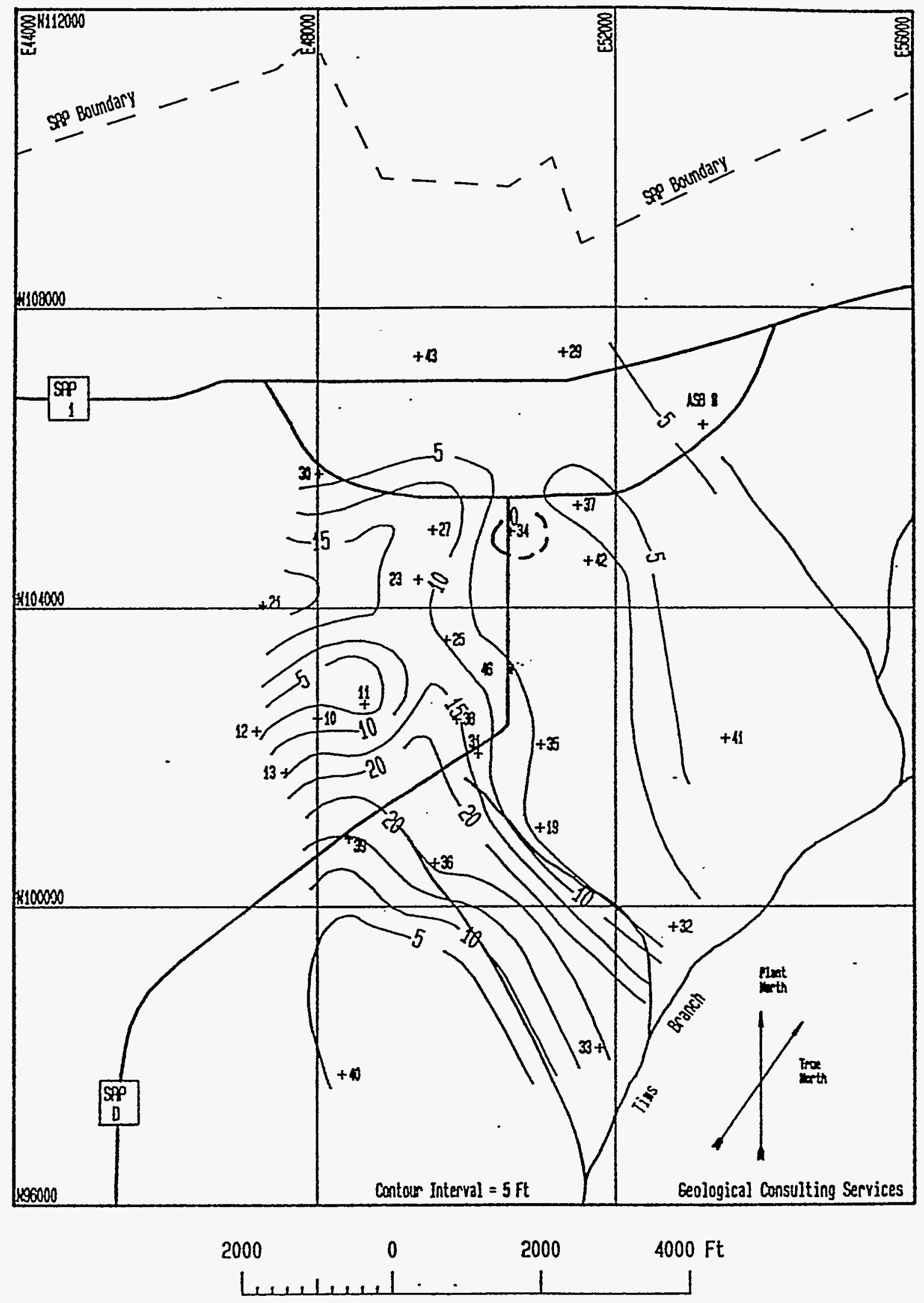

Figure 10. Isopach map, middle Ellenton clay.

$-21-$ 


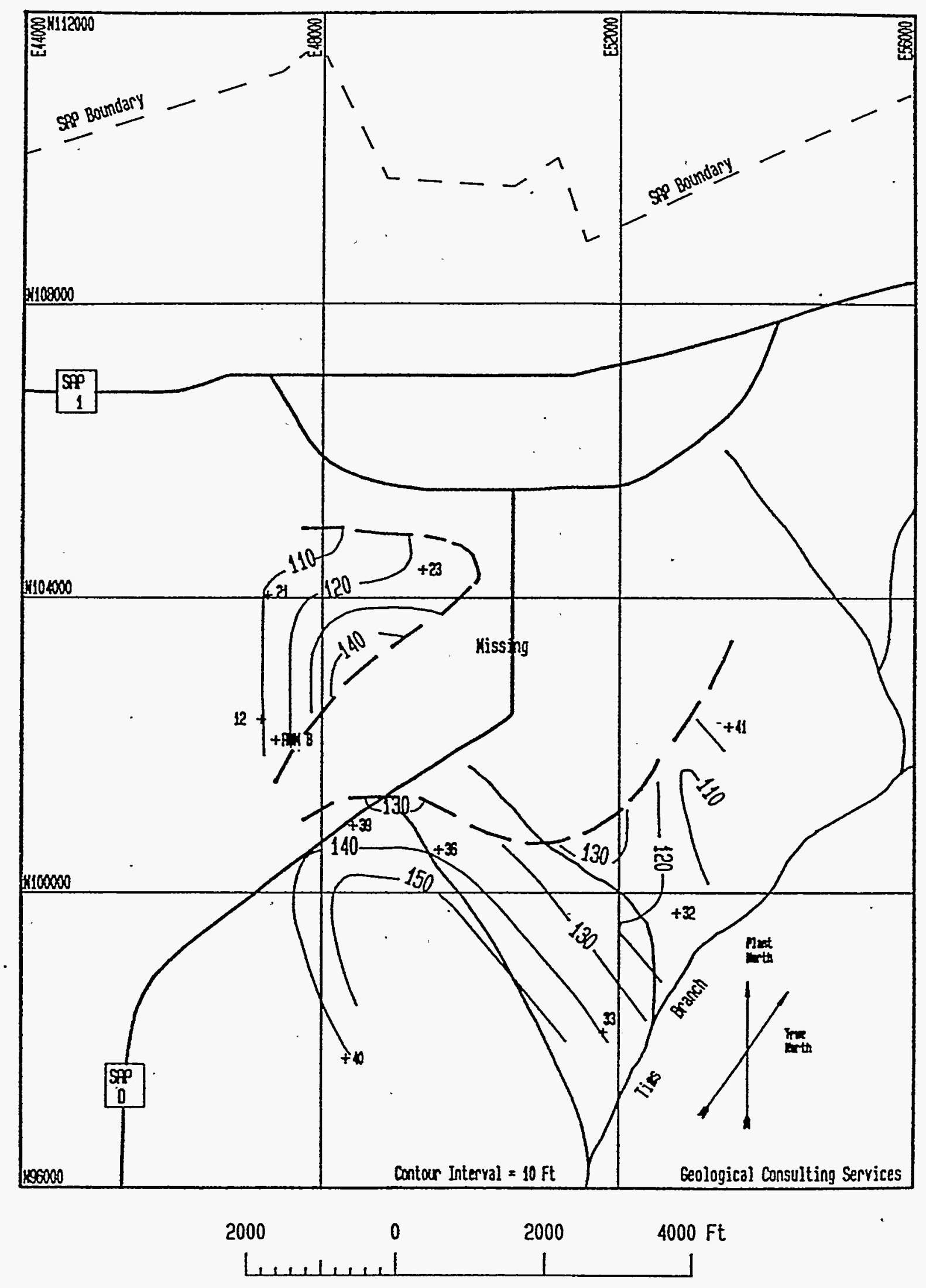

Figure 11. Structure contour map of top surface, upper Ellenton sand. 


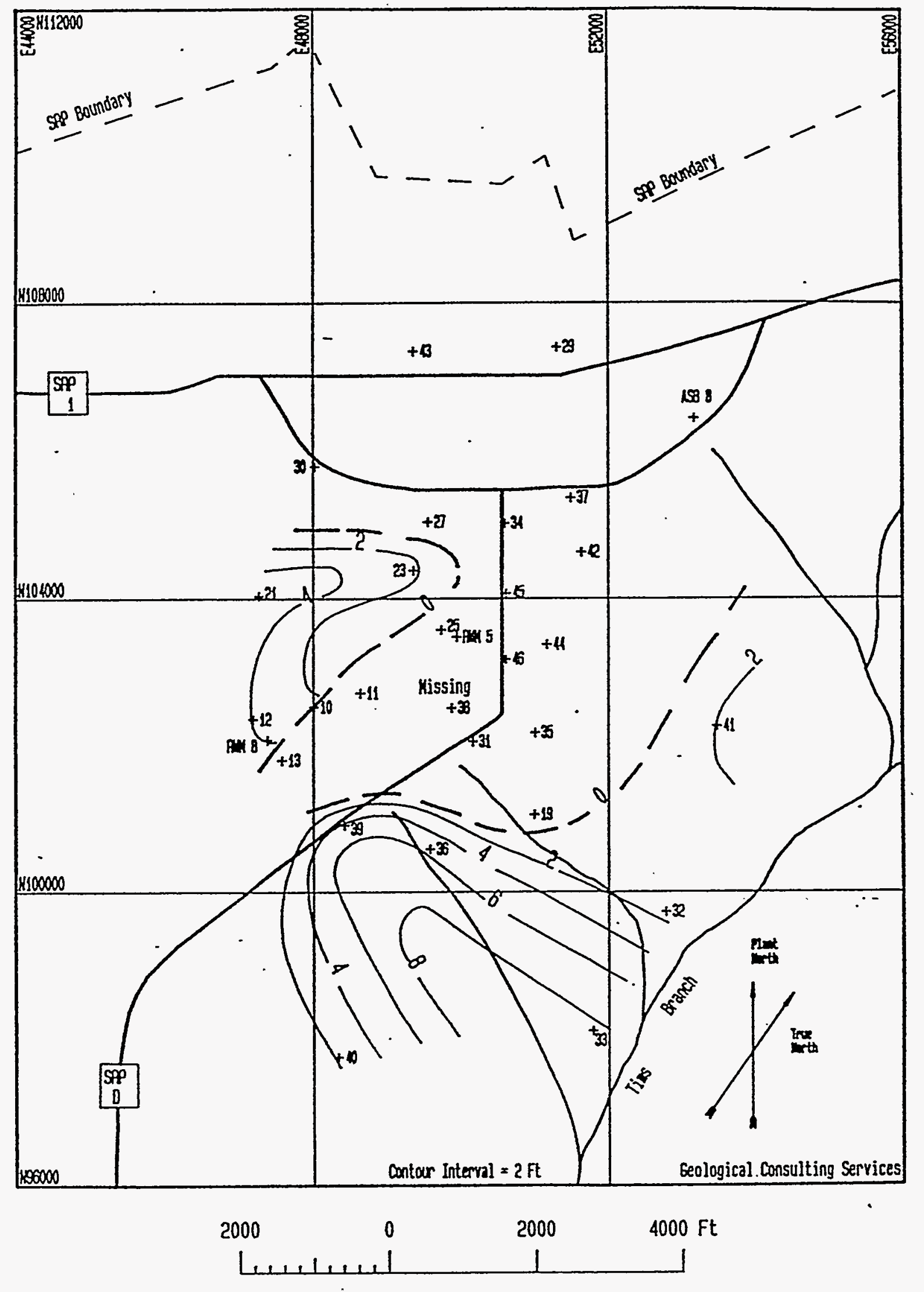

Fig. 12. Isopach map, upper Ellenton sand: 
Table 3. Ellenton Size Analysis Data (better sorted sands)

\begin{tabular}{|c|c|c|c|c|c|c|c|c|}
\hline $\begin{array}{l}\text { Well } \\
\text { Cluster }\end{array}$ & $\begin{array}{c}\text { Elevation } \\
\mathrm{ft}\end{array}$ & $\begin{array}{c}\text { Sand } \\
\%\end{array}$ & $\underset{\%}{\text { Silt }}$ & Clay & Median & $\begin{array}{c}\text { Mean } \\
6\end{array}$ & Sorting & Skewness \\
\hline MSB-10 & 119 & 65 & 20 & 15 & 2.7 & 3.5 & 2.5 & 0.4 \\
\hline MSB-11 & 132 & 88 & 6 & 6 & 1.4 & 1.6 & 2.5 & 0.3 \\
\hline MSB-11 & 130 & 91 & 6 & 3 & 1.2 & 1.3 & 1.9 & 0.2 \\
\hline MSB-19 & 117 & 95 & 2 & 3 & 0.5 & 0.7 & 1.3 & 0.4 \\
\hline
\end{tabular}

Table 4. Lower Congaree Size Analyses Date

\begin{tabular}{lcccccccc} 
Well & Elevation & Sand & Silt & Clay & Median & Mean & Sorting & Skewness \\
Cluster & ft & $\%$ & $\%$ & $\%$ & $\phi$ & $\phi$ & 6 & \\
\hline MSB-10 & 152 & 88 & 7 & 5 & 2.6 & 2.7 & 1.5 & 0.37 \\
MSB-10 & 150 & 88 & 11 & 1 & 2.2 & 2.2 & 1.0 & 0.02 \\
MSB-13 & 134 & 89 & 2 & 9 & 2.4 & 2.5 & 2.1 & 0.45 \\
MSB-13 & 132 & 88 & 6 & 6 & 0.9 & 1.5 & 2.9 & 0.47 \\
MSB-13 & 130 & 89 & 5 & 6 & 1.2 & 1.5 & 2.3 & 0.38
\end{tabular}

Table 5. Upper Congaree Size Analysis Data

\begin{tabular}{lcrrrrrrr}
\hline Wel1 & Elevation & Sand & Silt & Clay & Median & Mean & Sorting & Skewness \\
Cluster & $\mathrm{ft}$ & \multicolumn{1}{c}{$\%$} & \multicolumn{1}{c}{$\%$} & $\%$ & $\phi$ & $\phi$ & $\phi$ & \\
\hline MSB 11 & 178 & 56 & 20 & 24 & 3.5 & 4.8 & 4.1 & 0.42 \\
MSB 11 & 163 & 89 & 4 & 7 & 2.1 & 2.4 & 1.6 & 0.73 \\
MSB 11 & 162 & 30 & 27 & 43 & 7.0 & 7.1 & 4.1 & 0.05 \\
MSB 12 & 183 & 92 & 5 & 3 & 0.7 & 1.1 & 1.5 & 0.52 \\
MSB 12 & 181 & 93 & 6 & 1 & 0.5 & 0.9 & 1.4 & 0.48 \\
MSB 12 & 179 & 93 & 6 & 1 & 0.5 & 0.8 & 1.4 & 0.20 \\
MSB 12 & 161 & 92 & 6 & 2 & 0.9 & 13 & 1.6 & 0.44 \\
MSB 12 & 159 & 84 & 1 & 15 & 2.4 & 2.6 & 2.7 & 0.44 \\
MSB 12 & 157 & 55 & 7 & 1 & 3.3 & 6.0 & 4.9 & 0.65 \\
MSB 14 & 190 & 92 & 7 & 1 & 2.3 & 2.2 & 1.2 & 0.01 \\
MSB 17 & 160 & 86 & 3 & 11 & 1.8 & 2.1 & 2.1 & 0.61
\end{tabular}




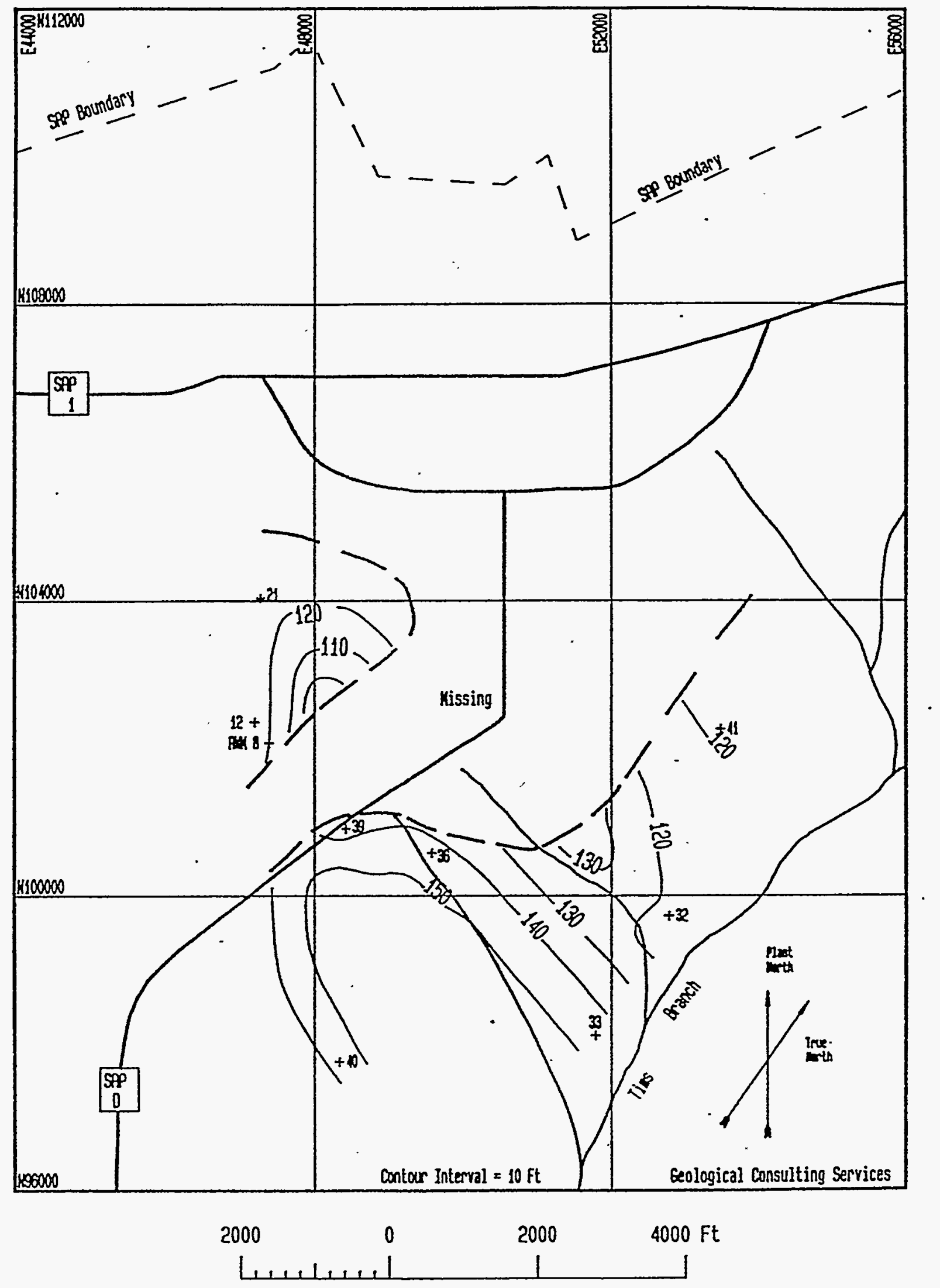

Figure 13. Structure contour map of top surface, upper Ellenton .clay. 


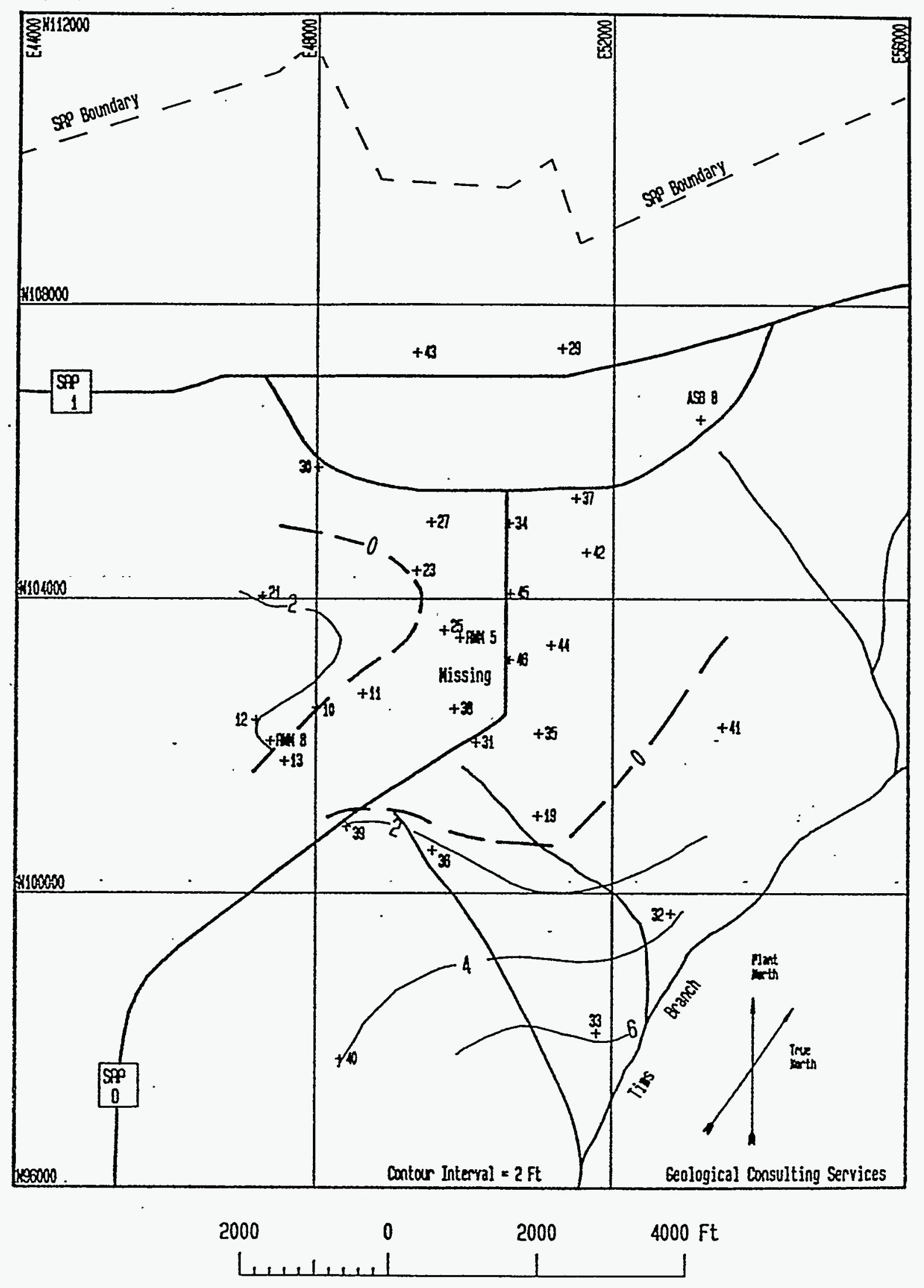

Figure 14. Isopach map, upper Ellenton clay. 
The upper clay is up to $6 \mathrm{ft}$ thick and is missing in some borings (See Figure 14). An Eocene age determination was made from microfossils in MSB-21. The contradictory paleontological age determinations from Ellenton samples in $A$ and $M$ areas may be caused by the paucity of fossils and by ignorance of the true stratigraphic ranges of the taxa. The lower clay had one Early Paleocene date and two questionable Eocene dates. The middle clay y.ielded one Eocene date. The upper sand had two Early Paleocene determinations, and the upper clay had a single Eocene date. Pollen dates from boring FC-5, several miles southeast of the study area, were Early Paleocene in deposits similar to the Ellenton in $A$ and $M$ areas. Further paleontological study is in progress on $A$ and $M$ cores.

The dark color, pyrite, and lignite, indicative of a reducing environment, suggest a deltaic or 'Tagoonal environment for the Ellenton. The decrease in grain size upward of the lower Ellenton sand would be expected in a deltaic distributary channel. The Ellenton clays may have been deposited in quieter environments between distributaries and seaward of the delta shoreline.

\section{Congaree Formation}

The Middle Eocene Congaree Formation is à sandy unit with a clayey zone in the lower middle part in most borings. The lower unconformable contact is picked where the dark clays of the Ellenton Formation meet the clean, yellowish sands of the Congaree. An iron oxide-cemented zone marks the contact in some borings. MSB-36 displays the contact very well. Gamma ray readings are generally high in the Ellenton and low in the Congaree. The upper boundary of the Congaree is picked where the Congaree sands meet the clay beds and clayier sands of the McBean Formation.. 


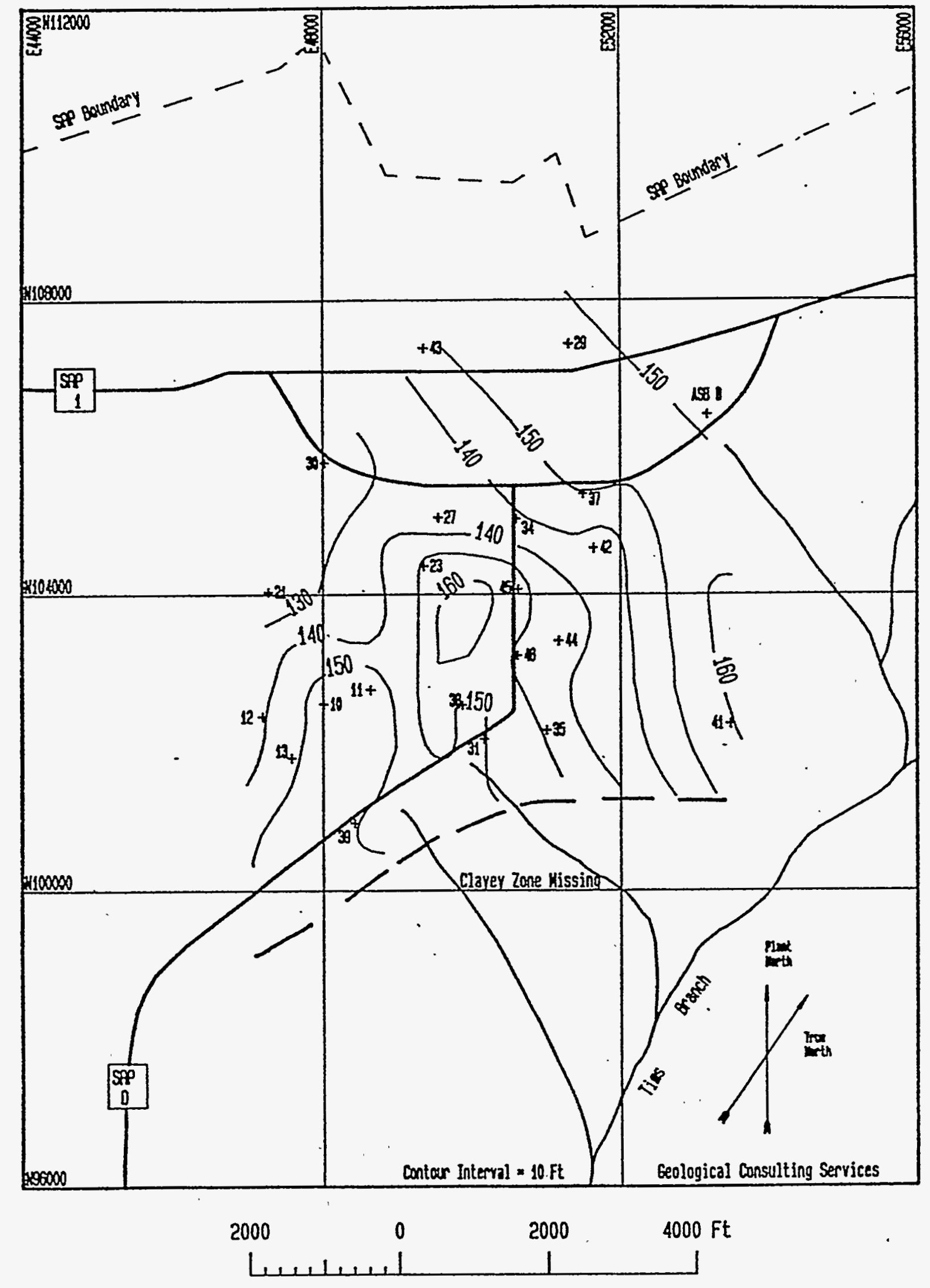

Figure 15. Structure contour map of top surface, lower Congaree sand. 
The lower Congaree sand (Figure 15) is brown, tan, and yellow; mediumgrained; and moderately well sorted. An average of. $17 \%$ of the entire unit is composed of clay and silt, and $6 \%$ of the section is made up of clay and silt beds. Clay laminae and heavy mineral zones occur in places. Pebbly layers are common, especially near the base. Thickness is from 4 to $44 \mathrm{ft}$. (See Figure 16). Table 4 gives data from size analyses.

The clayey zone in the Congaree (Figure 17) is a clay layer in some borings, and in others occurs as alternating sands and clays. A moderate gamma ray high and a low resistivity are usually logged through the interval. The zone is very thin or missing in the southern part of $A$ and $M$ areas (See Figures 17 and 18). The clayey zone appears to vary in stratigraphic position, sometimes appearing very low in the Congaree and sometimes higher. It is possible that there is more than one clayey zone. The interval is gray, tan, and, rarely, green, orange, brown, or purple. An average of $70 \%$ of the zone is composed of clay and sitt beds, and $72 \%$ of al7 sediments are clay and silt. The sands in the zone are medium- to fine-grained and well sorted. Thickness varies from 0 to $43 \mathrm{ft}$. (See Figure 18). Middle Eocene pollen occurs in MSB-18.

The upper Congaree sand (Figure 19) is yellow, tan, and brown, mediumand fine-grained, well-sorted sand. Heavy mineral zones are common, as are pebbly zones and clay balls. Clay and silt beds make up an average of 7\% of the section, and $16 \%$ of all material in the unit is clay and silt. Clay Taminae occur in most borings and micaceous zones occur in some. The unit is from 14 to $60 \mathrm{ft}$ thick. (See Figure 20) Table 5 shows size frequency distribution data. 


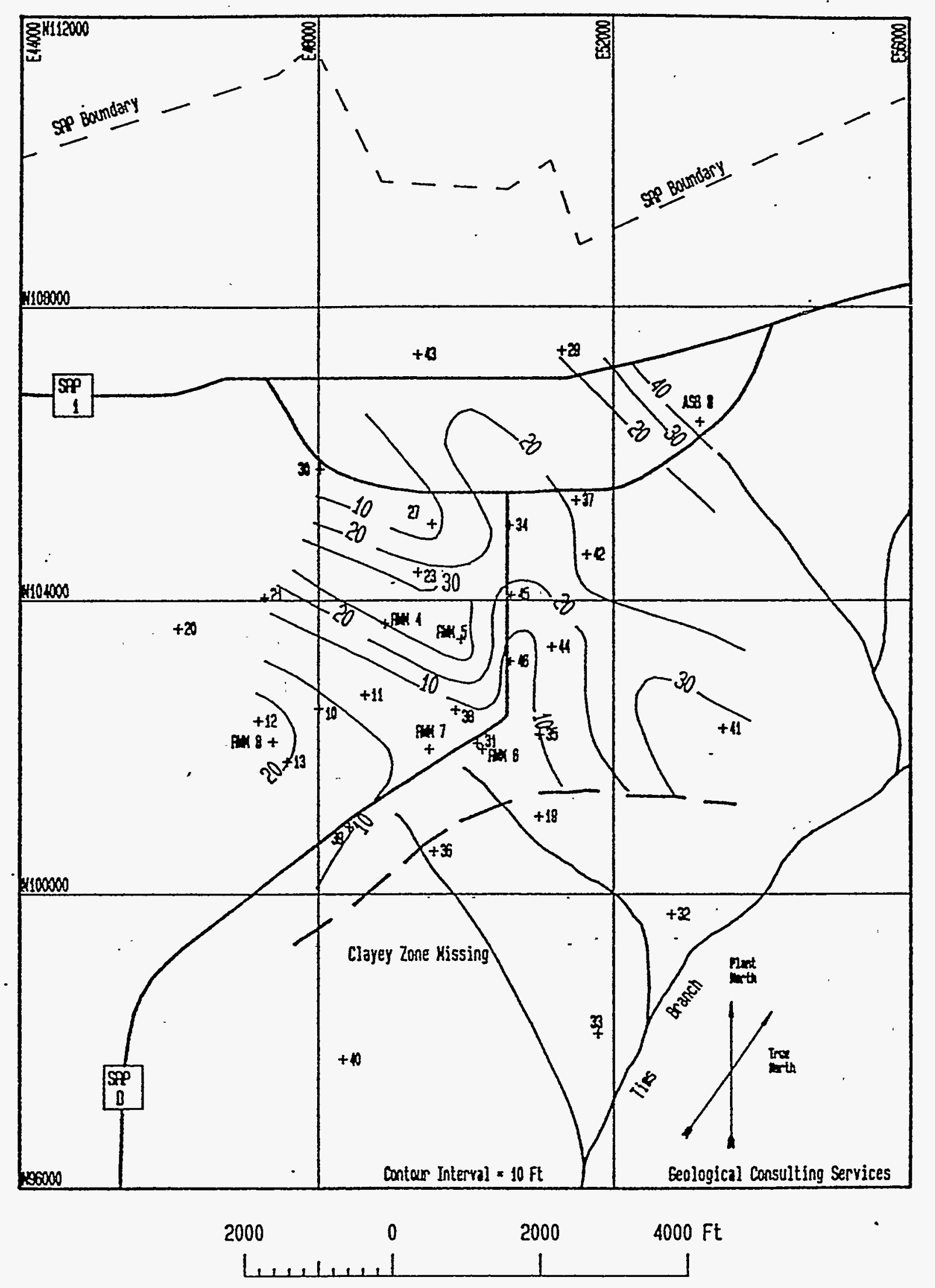

Figure 16. Isopach map, Tower Congaree sand 


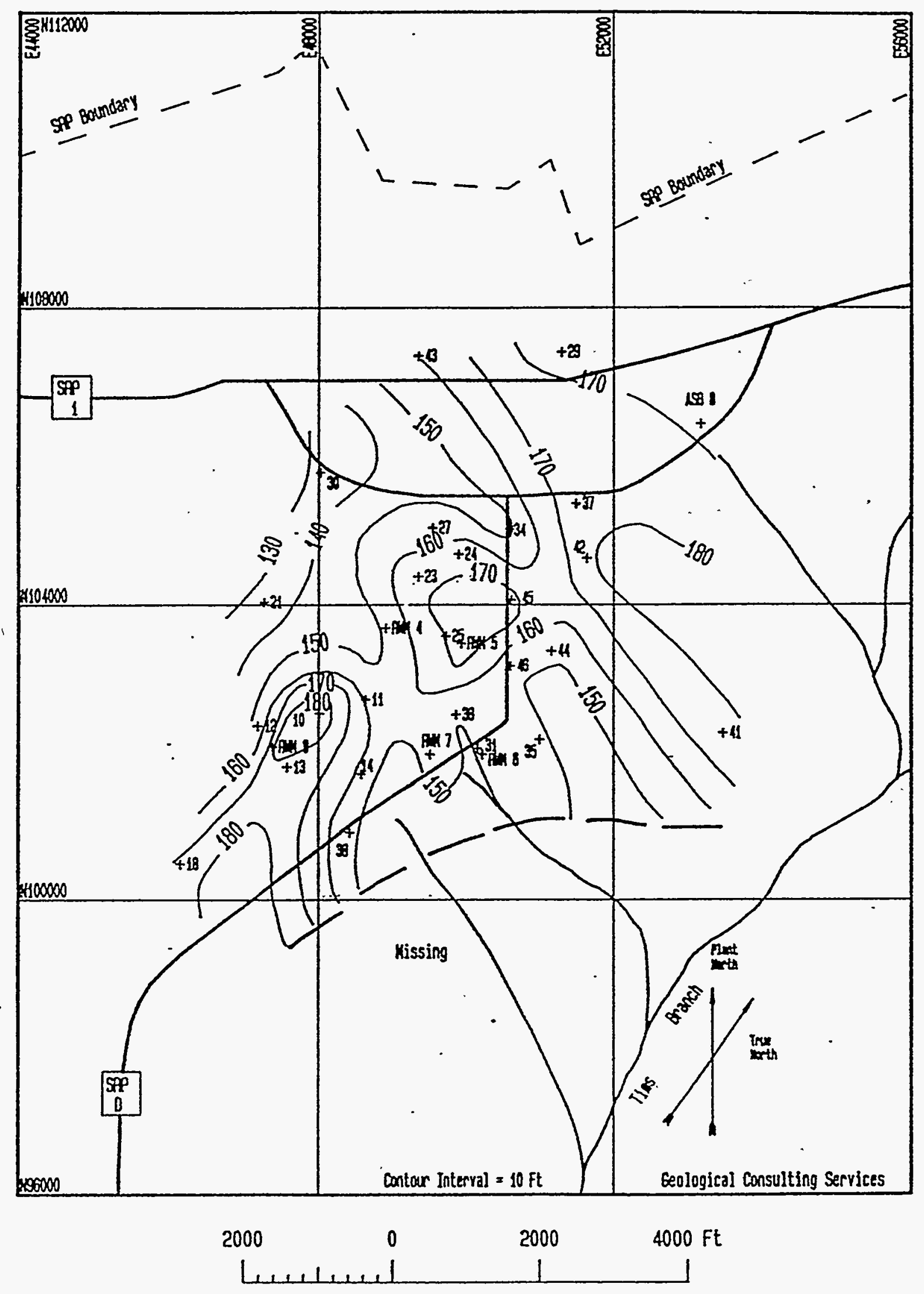

Figure 17. Structure contour map of top surface, Congaree clayey zone. 


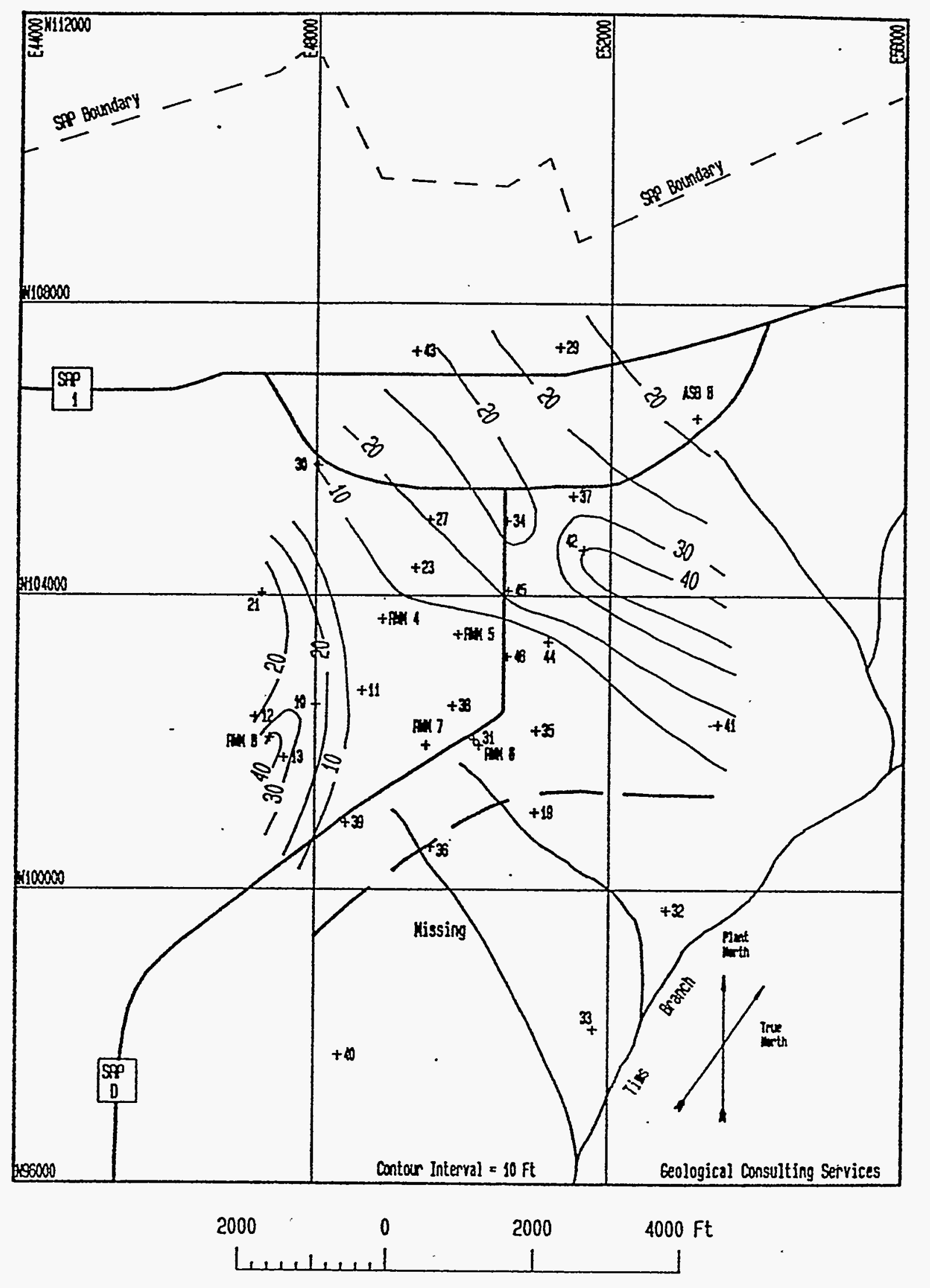

Figure 18. Isopach map, Congaree clayey zone. 


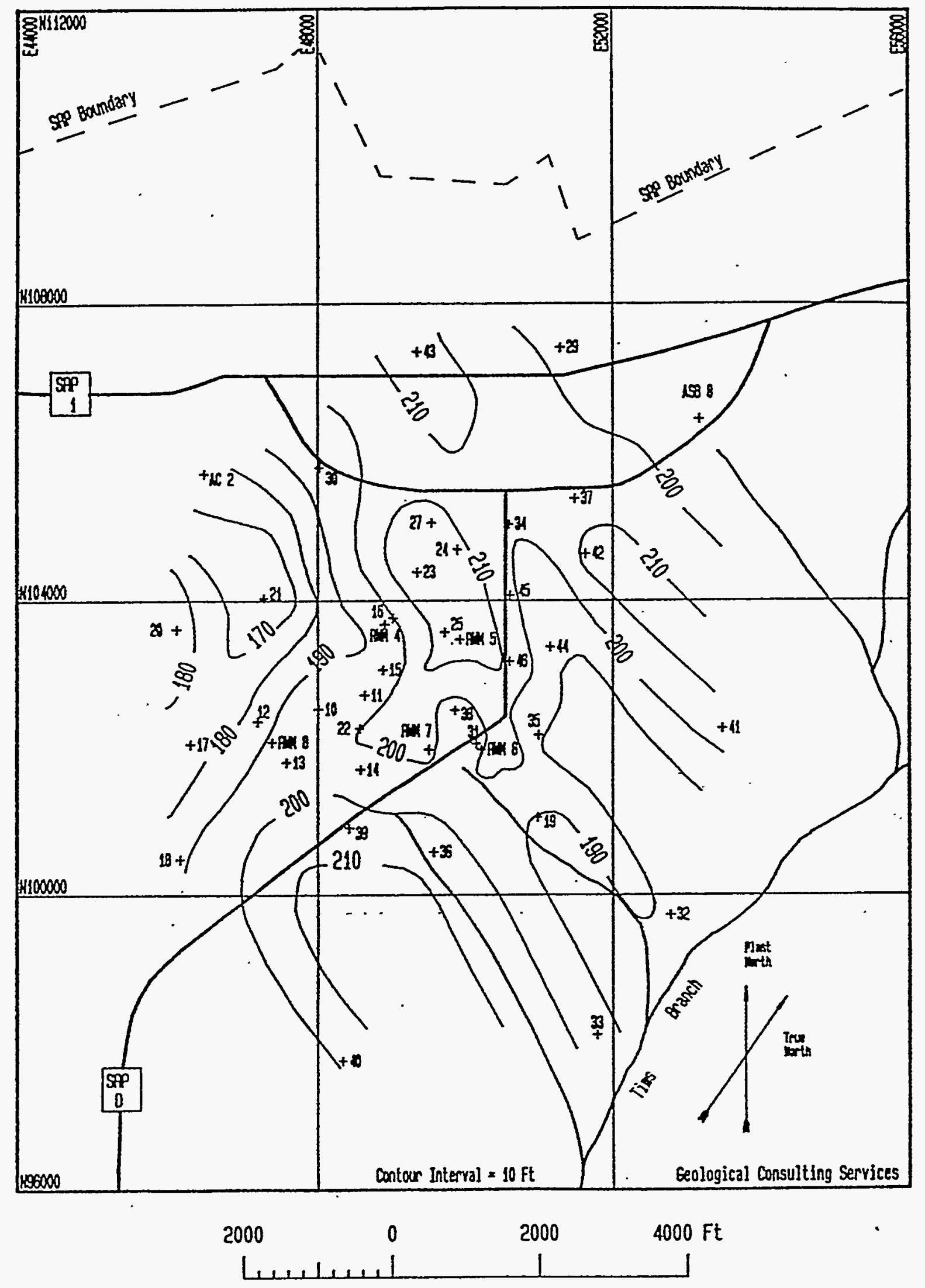

Figure 19. Structure contour map of top surface, Congaree Formation 


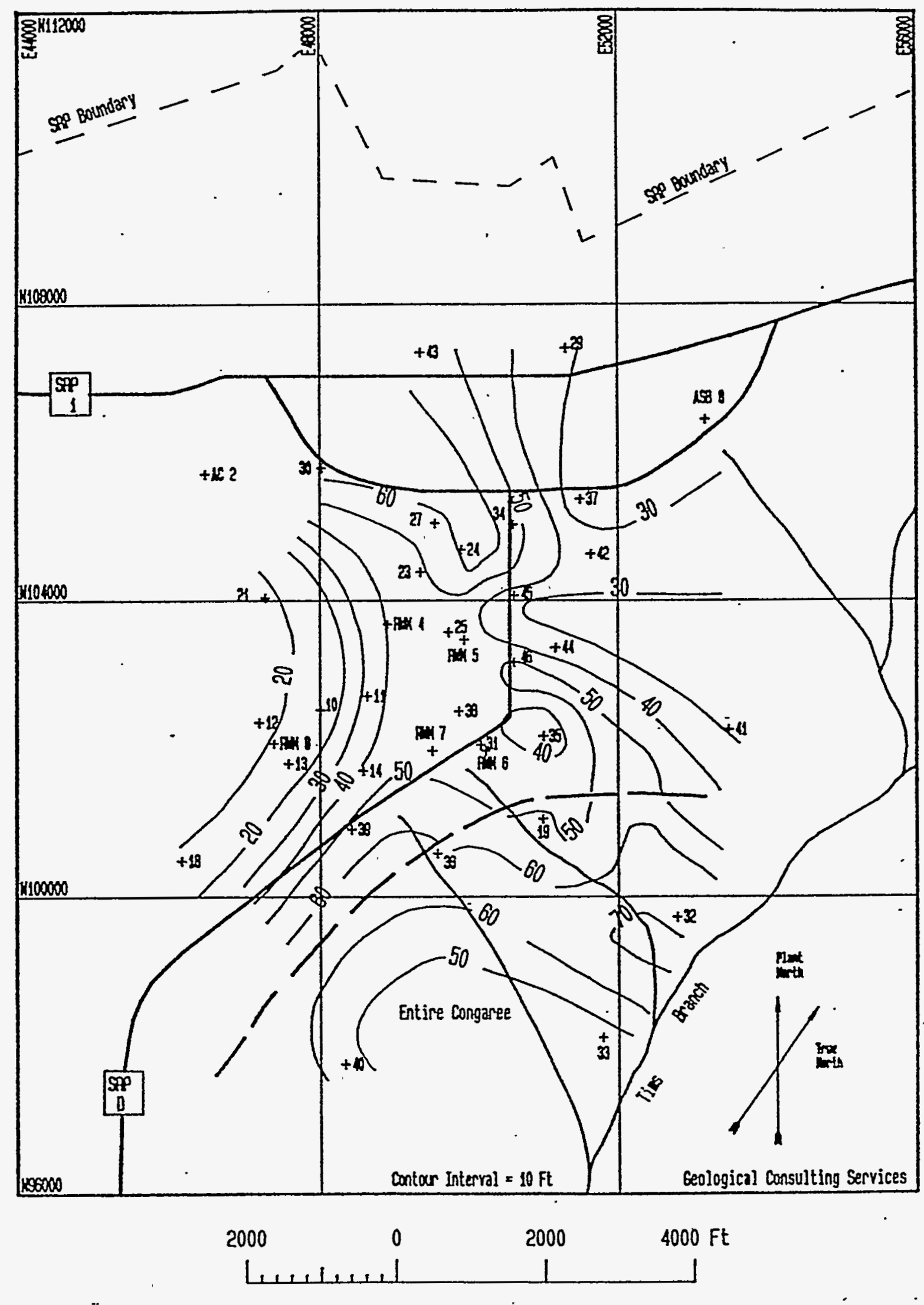

Figure 20. Isopach map, upper Congaree sand. 


\section{McBean Formation}

Limestone occurs at the type locality of the Middle Eocene McBean Formation across the Savannah River in Georgia. Calcareous deposits are found in the Middle Eocene section above the Congaree in many SRP borings. MSB-40, on the southern edge of $A$ and $M$ areas contains $7 \mathrm{ft}$ of 7 imestone in a $28 \mathrm{ft}$ section composed mostly of glauconitic, poorly-sorted sand, with a thin clay at the top. (See Appendix Figure A36). Other borings in the study area lack the limestone, but a gamma ray high in MSB-40, corresponding to the section of glauconitic sand, limestone, and clay, can be found in most borings. Silicified mollusks were found in MSB-11. In most borings, the section contains more clay, either as clay layers or as matrix in sands, than in the underlying upper Congaree sand and the overlying Dry Branch Formation (Table 6). It also is more micaceous. An unconformity may separate the McBean from the underlying Congaree.

The McBean section is usually orange and yellow. Clay and silt beds average $14 \%$ of the unit, and clay and silt make up $25 \%$ of all sediments. In the northern part, the formation appears to be more permeable than elsewhere in $A$ and $M$ areas (Figure 22). The sands are fine-grained and well, moderate$7 y$, and poorty sorted. Pebbles and clay balls occur in some borings, and muscovite is found in most. There does not apepar to be an extensive, continuous Tayer of green clay at the bottom nor a $\tan$ clay at the top, as has been re-

ported elsewhere in SRP, but clay layers of gray, green, tan, and other colors occur at various stratigraphic horizons within the McBean. Thickness of the formation is from 16 to $34 \mathrm{ft}$ in borings (See Figure 23). Dinoflagellates and pollen from MSB-79 yielded a Middle Eocene date. Table 7 shows size data from sieve and hydrometer analysis. 


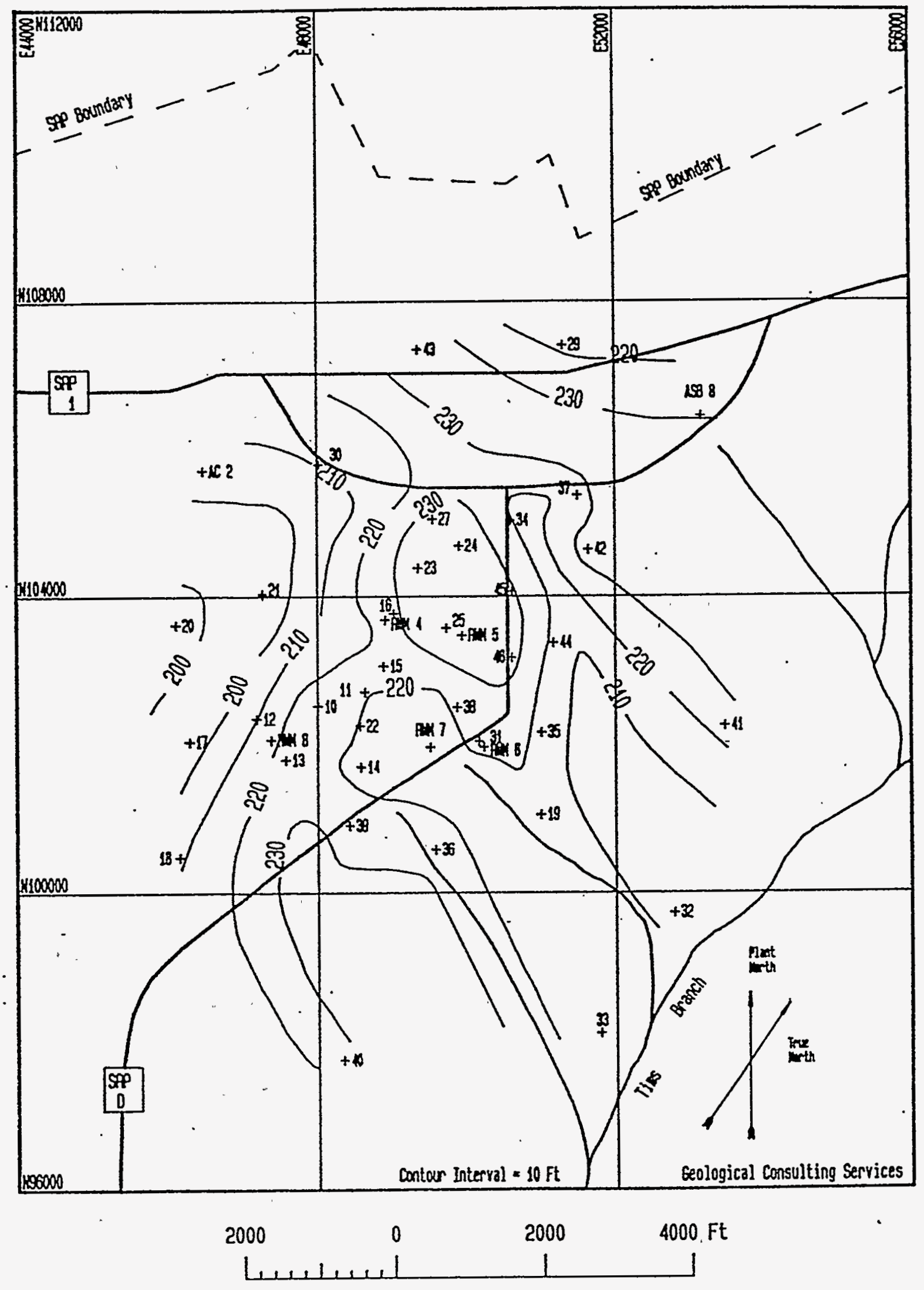

Figure 21. Structure contour map of top surface, McBean Formation. 


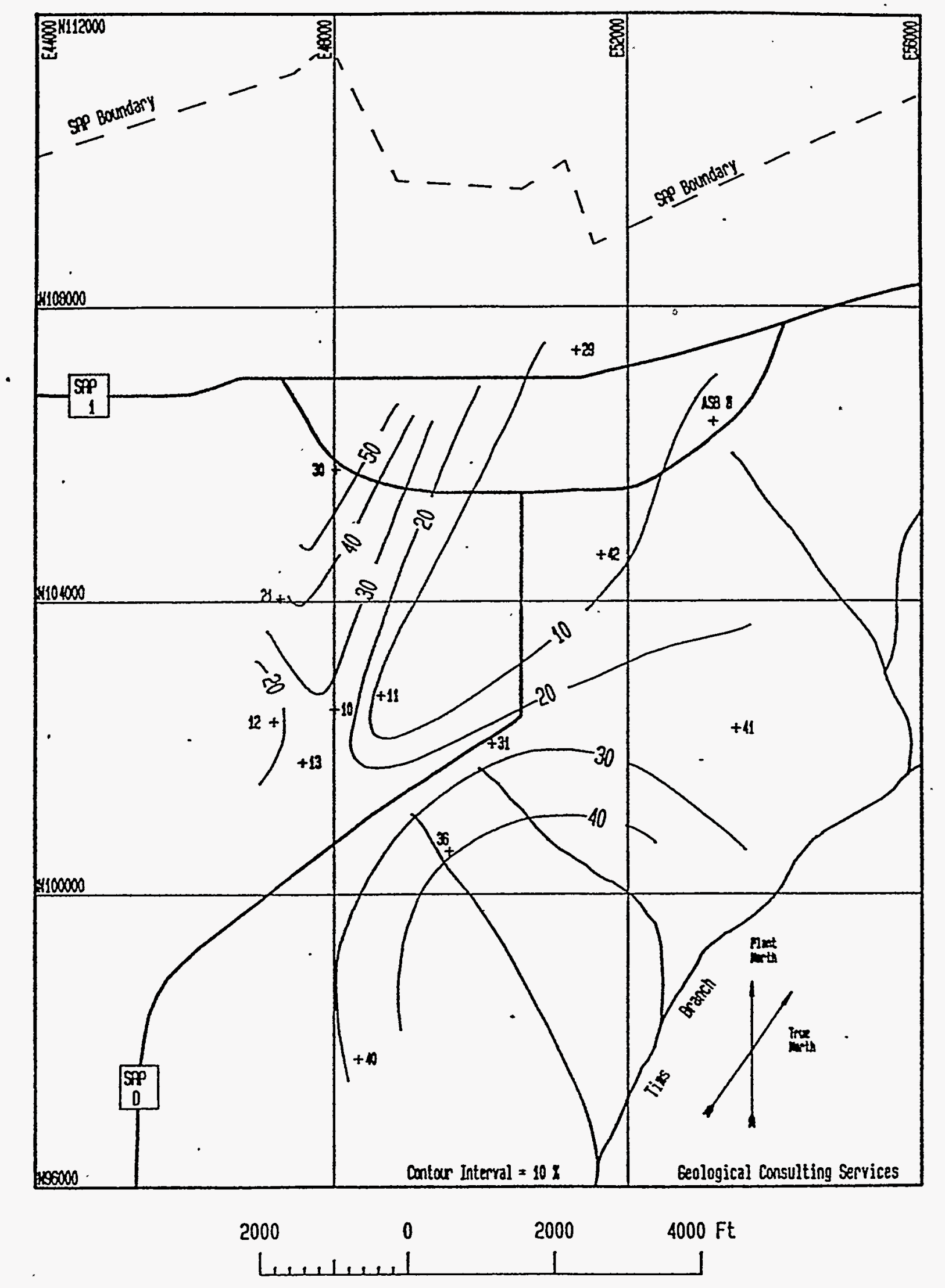

Figure 22. Percentage of silt and clay in the McBean Formation. 


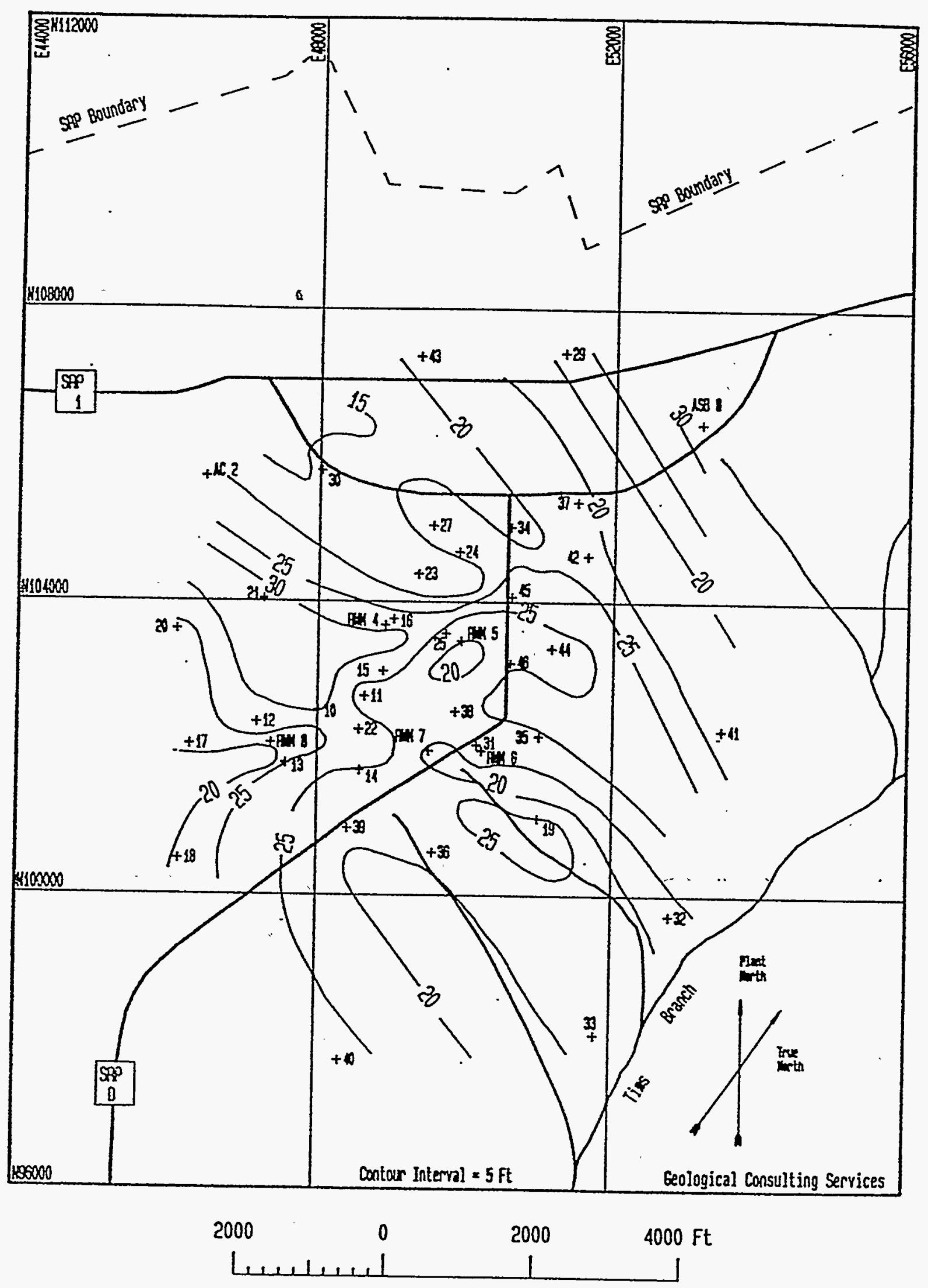

Figure 23. Isopach map for the McBean Formation. 


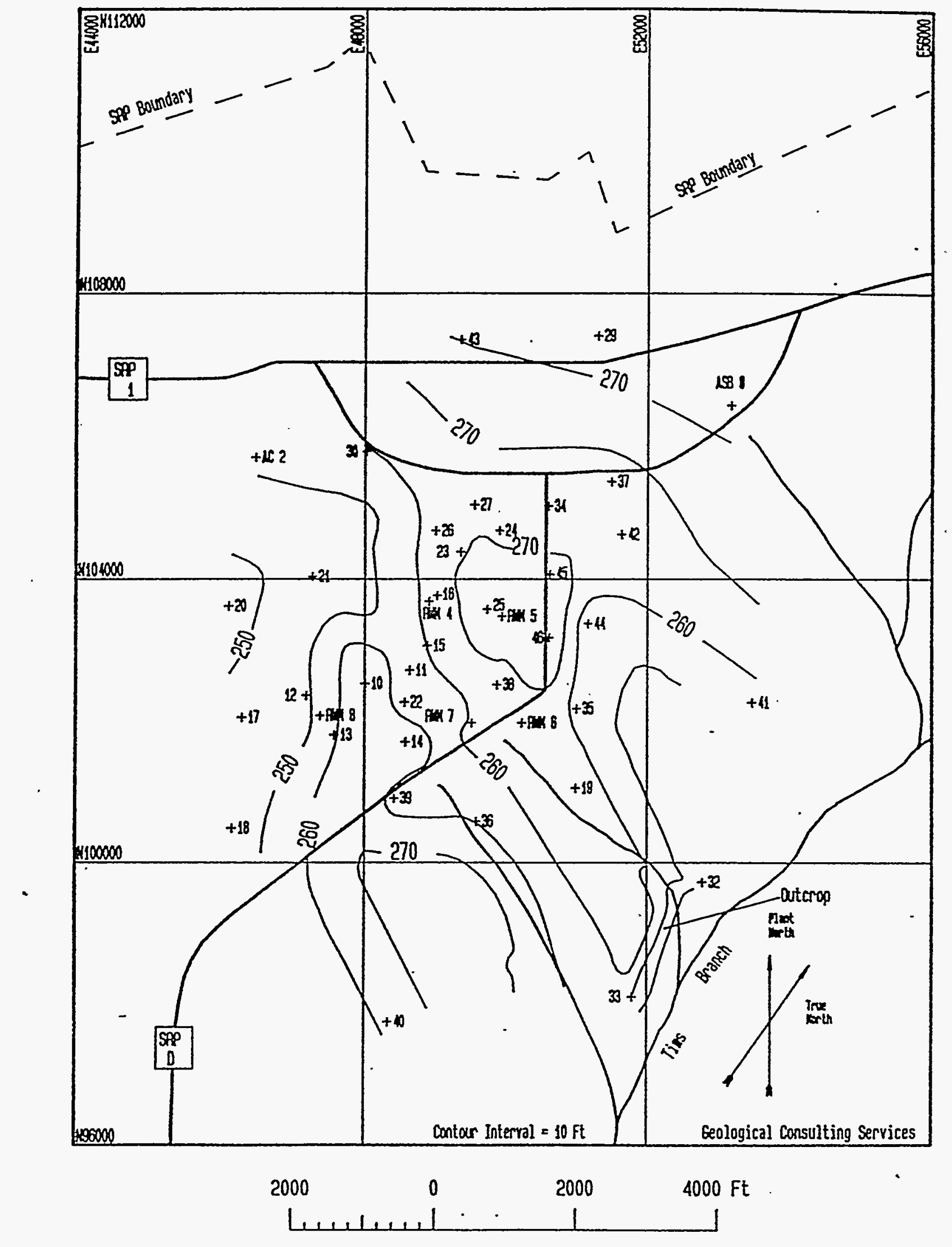

Figure 24. Structure contour map of top surface, Dry Branch Formation. 
Table 6. Average $\mathrm{Clay}$ and Silt Content from Visual Analysis

\begin{tabular}{lcc}
$\begin{array}{c}\text { Stratigraphic } \\
\text { Unit }\end{array}$ & $\begin{array}{c}\text { As matrix in sands } \\
\text { and as beds } \\
\%\end{array}$ & $\begin{array}{c}\text { As beds } \\
\%\end{array}$ \\
\hline Upland unit & 52 & 49 \\
Tobacco Road & 13 & 2 \\
Dry Branch & 18 & 11 \\
McBean & 25 & 14 \\
Upper Congaree & 16 & 7 \\
Congaree clayey zone & 72 & 70 \\
Lower Congaree & 17 & 6 \\
El-Tenton & 62 & 59 \\
Black Creek (upper 30 ft) & 22 & 5
\end{tabular}

Table 7. McBean Size Analysis Data

\begin{tabular}{lccrccccc}
$\begin{array}{l}\text { Well } \\
\text { CTuster }\end{array}$ & $\begin{array}{c}\text { Elevation } \\
\mathrm{ft}\end{array}$ & $\begin{array}{c}\text { Sand } \\
\%\end{array}$ & $\begin{array}{c}\text { SiTt } \\
\%\end{array}$ & $\begin{array}{c}\text { CTay } \\
\%\end{array}$ & $\begin{array}{c}\text { Median } \\
\sigma\end{array}$ & $\begin{array}{c}\text { Mean } \\
6\end{array}$ & $\begin{array}{c}\text { Sorting } \\
6\end{array}$ & Skewness \\
\hline MSB 10 & 270 & 77 & 10 & 13 & 2.8 & 3.1 & 3.2 & 0.29 \\
MSB 10 & 208 & 82 & 10 & 8 & 1.7 & 2.1 & 2.5 & 0.46 \\
MSB 10 & 205 & 93 & 6 & 1 & 1.5 & 1.6 & 1.2 & 0.27 \\
MSB 11 & 208 & 79 & 16 & 5 & 3.4 & 3.7 & 1.3 & 0.57 \\
MSB 11 & 206 & 54 & 38 & 8 & 3.8 & 4.3 & 2.1 & 0.39 \\
MSB 11 & 204 & 71 & 21 & 8 & 3.1 & 3.3 & 2.5 & 0.29 \\
MSB 17 & 190 & 47 & 43 & 10 & 4.2 & 4.7 & 2.1 & 0.39 \\
MSB 17 & 185 & 85 & 4 & 11 & 2.0 & 2.6 & 2.8 & 0.58
\end{tabular}


Dry Branch Formation

The Dry Branch (Figure 24) is the Tower formation in the Late Eocene Barnwell Group and unconformably overlies the McBean. The sands of the Dry Branch are coarser and cleaner than those in the McBean, and a pebbly layer occurs at the base in some borings. The top of the unit is picked where the yellower sands with clay laminae meet the redder sands of the Tobacco Road which tend to 1ack clay 1aminae. The Dry Branch is composed of orange, brown, and yellow, medium-grained, moderately- and well-sorted sand. Clay and silt beds compose an average of $11 \%$ of the formation, and clay and silt constitute $18 \%$ of all the sediments. Clay laminae are common. There does not appear to be an extensive layer of tan clay anywhere in the formation. Clay layers, however, usually tan, occur at various stratigraphic horizons within the Dry Branch. Pebbly layers are common. Thickness of the formation is from 30 to $55 \mathrm{ft}$ (See Figure 25).

Tobacco Road Formation

The upper unit of the Barnwell Group, the Tobacco Road Formation (Figure 26) is characterized in many outcrops by a concentration of flat quartz pebbles at its base. In MSB-15 and -24, (See Appendix Figures A17 and A19) flat quartz pebbles were found at an obvious lithologic change. A gamma ray kick occurs there. The base of the formation was picked in other borings either by 1ithology or by a gamma ray kick. The upper contact was picked where the fairly well-sorted sands of Tobacco Road change to clayey, silty, sandy, pebbly, and poorly-sorted beds of the Upland unit.

The Tobacco Road is brown, orange, yellow, red, and purple. Medium and fine sands, moderately and well sorted, compose nearly the entire formation. An average of $13 \%$ of $a 77$ the sediments are clay and silt. Clay and silt layers make up only $2 \%$ of the section. Pebbly layers are common, especially near the base. Clay balls occur in some borings. 
The thickness, controlled part7y by erosion accompanying deposition of the overlying Upland unit, and partly by post-Upland unit erosion, varies from 0 in stream valleys to about $97 \mathrm{ft}$. (See Figure 27). Both the Tobacco Road and the Dry Branch were probably deposited during the Late Eocene marine transgression. The latter formation with its clay layers formed during the transgressive phase and the younger Tobacco Road was deposited during the regressive phase.

Upland Unit

Capping the higher areas in SRP is a deposit of coarse-, medium- and finegrained, poorly sorted, pebbly and cobbly material with extreme lateral and vertical variation. The South Carolina Geological Survey has been mapping it as the informally named "Upland unit." It partially corresponds to sediments previousty mapped in SRP as the Hawthorn Formation.

In $A$ and $M$ areas, the unit is orange, brown, red, and tan. Sorting is very poor. Clay and silt make up about $50 \%$ of the deposits. Pebbly zones are abundant. Feldspar grains occur in places. Thickness is from 0 to $57 \mathrm{ft}$. (See Figure 28). It was probabiy deposited in high energy fluvial channels, point bars, flood plains, and abandoned channels. The channels seem to have cut down into the Tobacco Road in places, forming a very irregular surface at its top. 


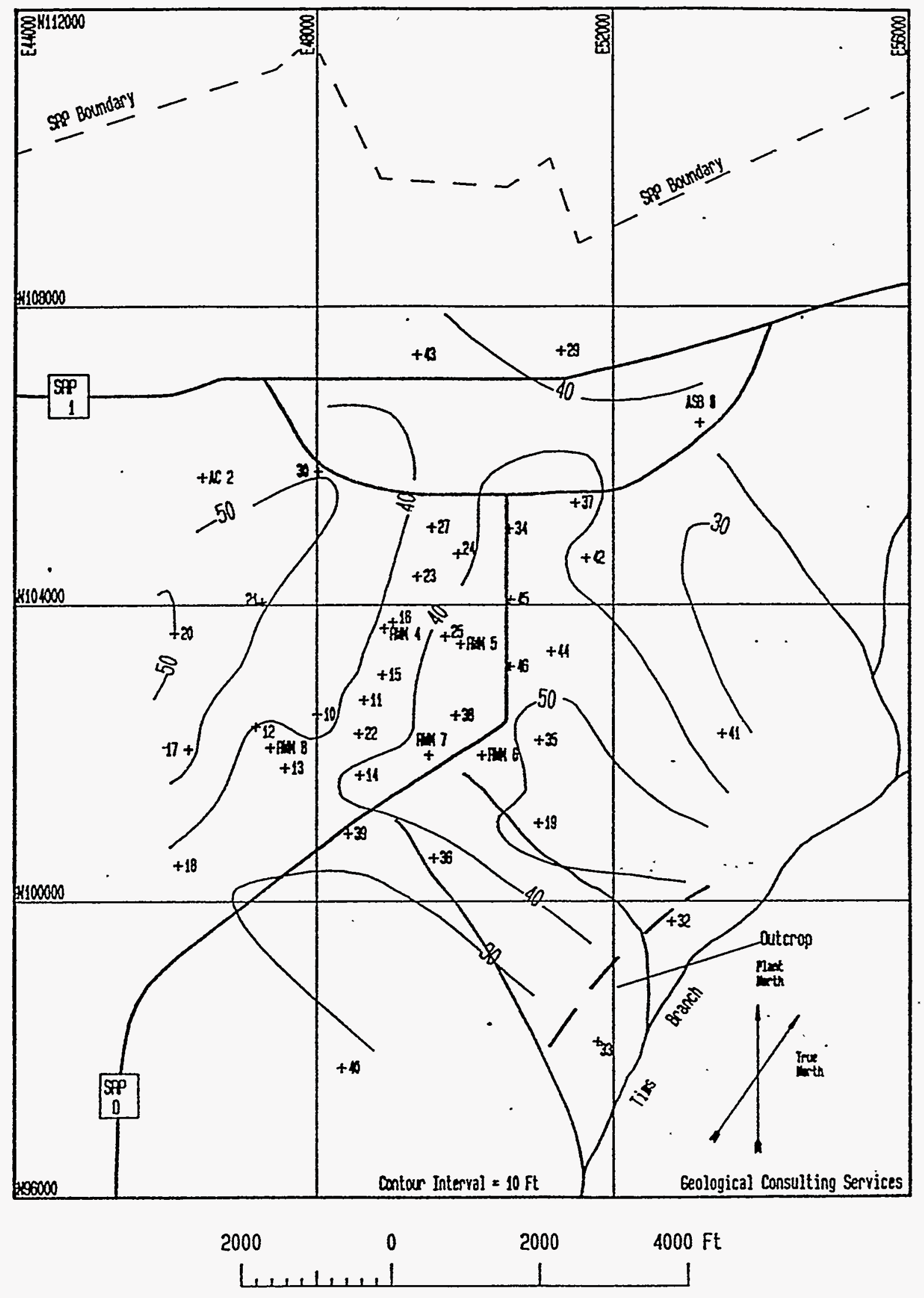

Figure 25. Isopach map, Dry Branch Formation. 


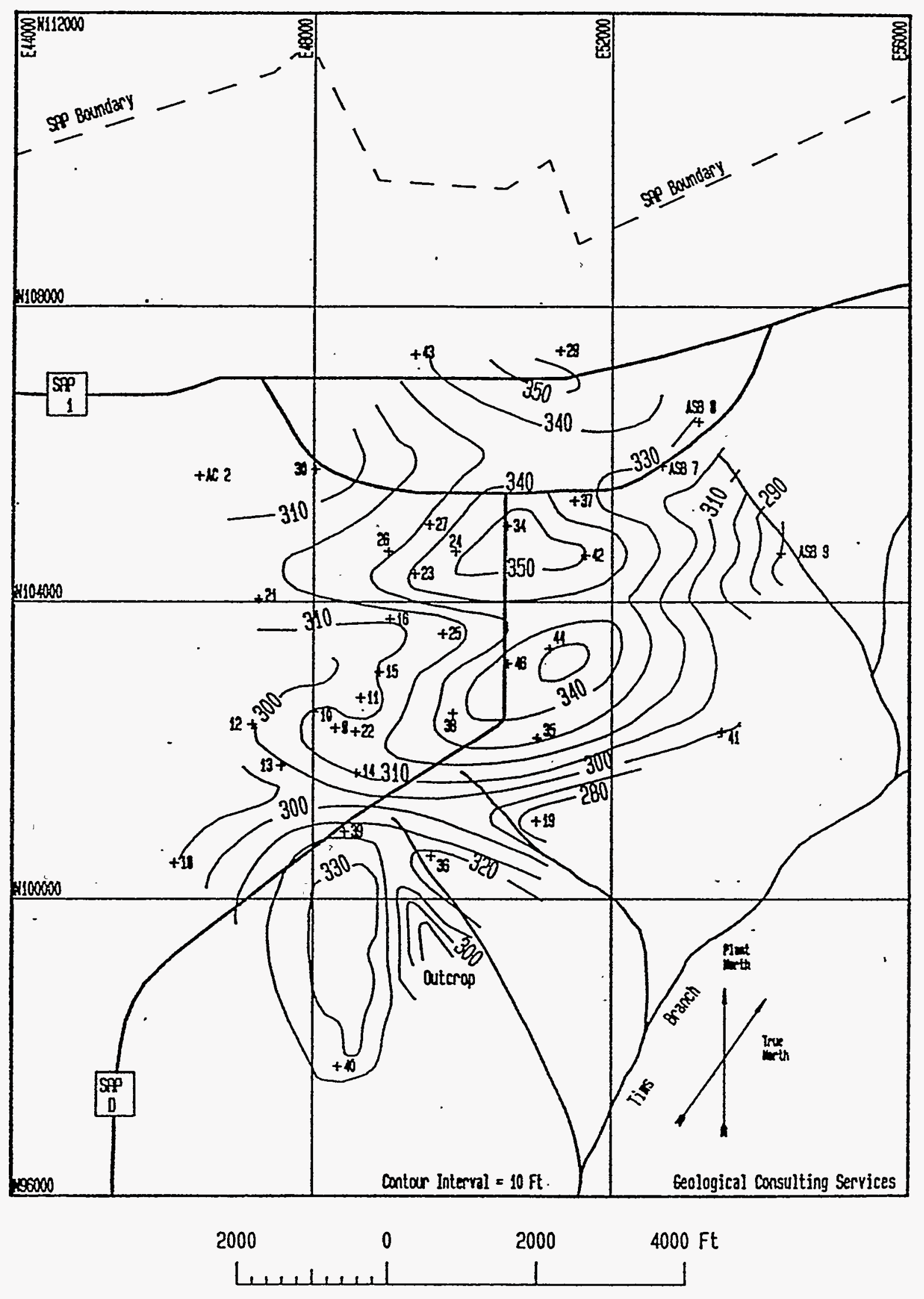

Figure 26. Structure contour map of top surface, Tobacco Road Formation. 


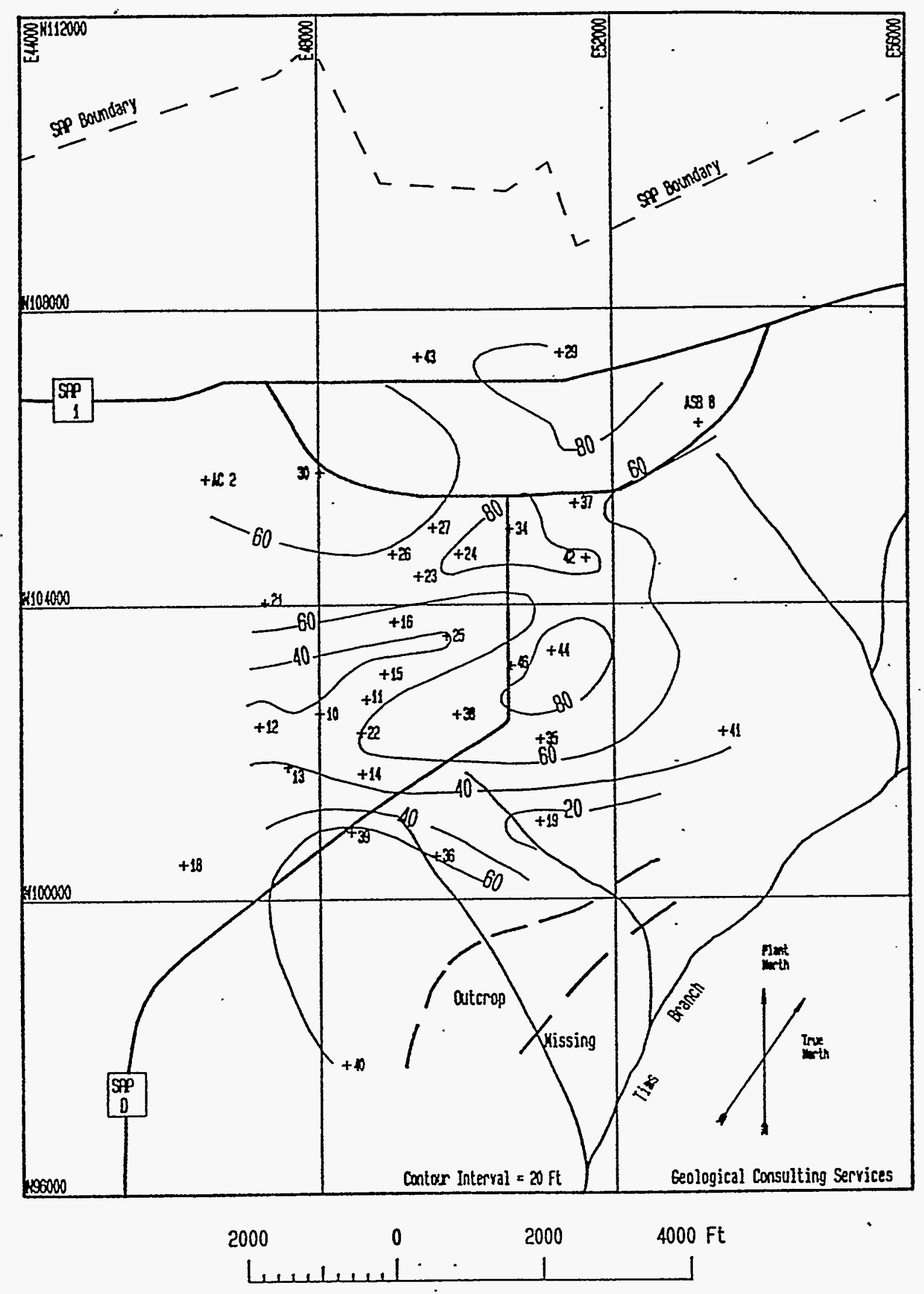

Figure 27. Isopach map, Tobacco Road Formation. 


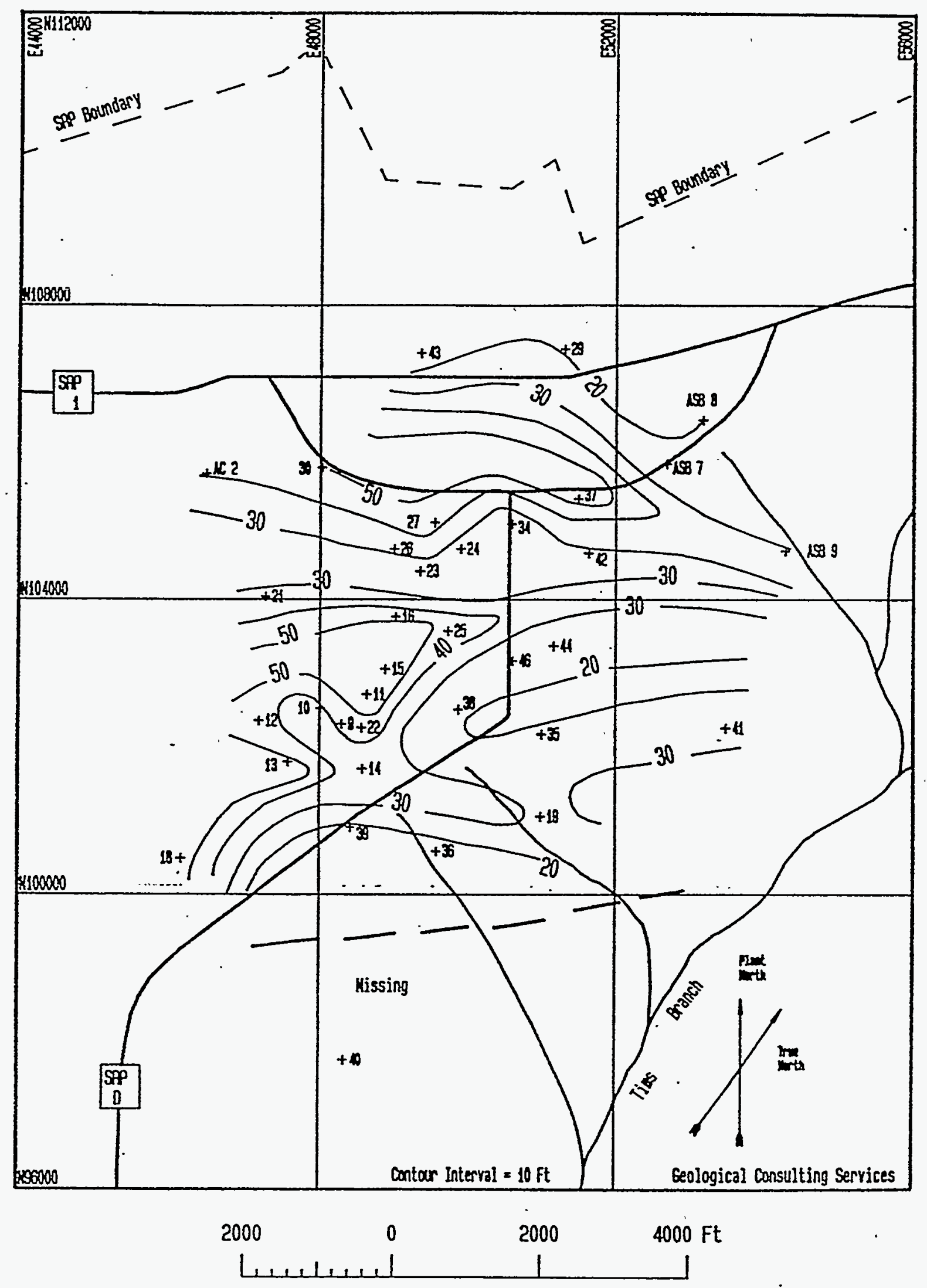

Figure 28. Isopach map, Upland unit. 
STRUCTURE

Cross-sections through the area (Figure 29) were prepared using the structure contour maps as a guide. The highs and lows betwen borings on the cross-sections (Figures 30-34) were inferred from the structure contour maps. Dips are up to about $260 \mathrm{ft} / \mathrm{mi}\left(3^{\circ}\right)$ for the Black Creek Formation and generalTy decrease going up the stratigraphic section. A plausible sequence of events leading to the development of the structures is:

Deposition of sediment

Erosion during unconformity development, probably caused by drop in sea lever

Deposition on irregular erosion surface, with thicker sediments being deposited in topographic lows

Differential compaction causing thicker sediments and clayey sediments to subside more than thinner sediments and sandier sediments

Erosion during unconformity development

This process would be modified by lateral changes in patterns of sedimentation during deposition of each formation. A barrier island, for example, would. cause sediments to build higher than the adjacent shallow sea floor.

The structural grain (trends of highs and lows) shown on the structure contour maps (Figures $2,3,5,7,9,17,13,15,17,19,21,24,25$ ) is general1y northwest-southeast, parallel to regional slope. An exception to this is the top of the Tobacco Road Formation which is also the lower surface of the Up7 and unit (See Figure 26). This surface shows a grain which generally trends northeast-southwest. Erosion here may have been controlled by streams flowing toward the Savannah River rather than toward the At7antic Ocean. 


\section{SUMMARY}

The stratigraphic units beneath $A$ and $M$ areas are mostly sands. Extensive clays occur at the top of the Cretaceous Middendorf Formation, within the Paleocene Ellenton Formation, the Eocene Congaree Formation, the Eocene McBean Formation, and the Upland unit (age unknown) Carbonates were found in only the southern part of the study area.

Cross-sections, structure contour maps, and isopach maps show that stratigraphic units change in thickness, contacts are irregular rather than planar, and local dips vary in direction.

The coring and geophysical logging that will accompany future monitor well installation in the $A$ and $M$ areas will greatly aid in the refining of the stratigraphic and structural model presented here. Of especial help would be the expansion of the drilling effort towards Tims Branch which would enable this study to be correlated with studies in the $F$ and $H$ areas.

Further detailed sedimentological investigations of the available cores and the obtaining of additional age determinations should also.be considered. During the summer of 1986, an investigation of the so-called "calcareous zone" is being conducted at SRP and should provide answers to many questions concerning the age and correlation of these sediments. 


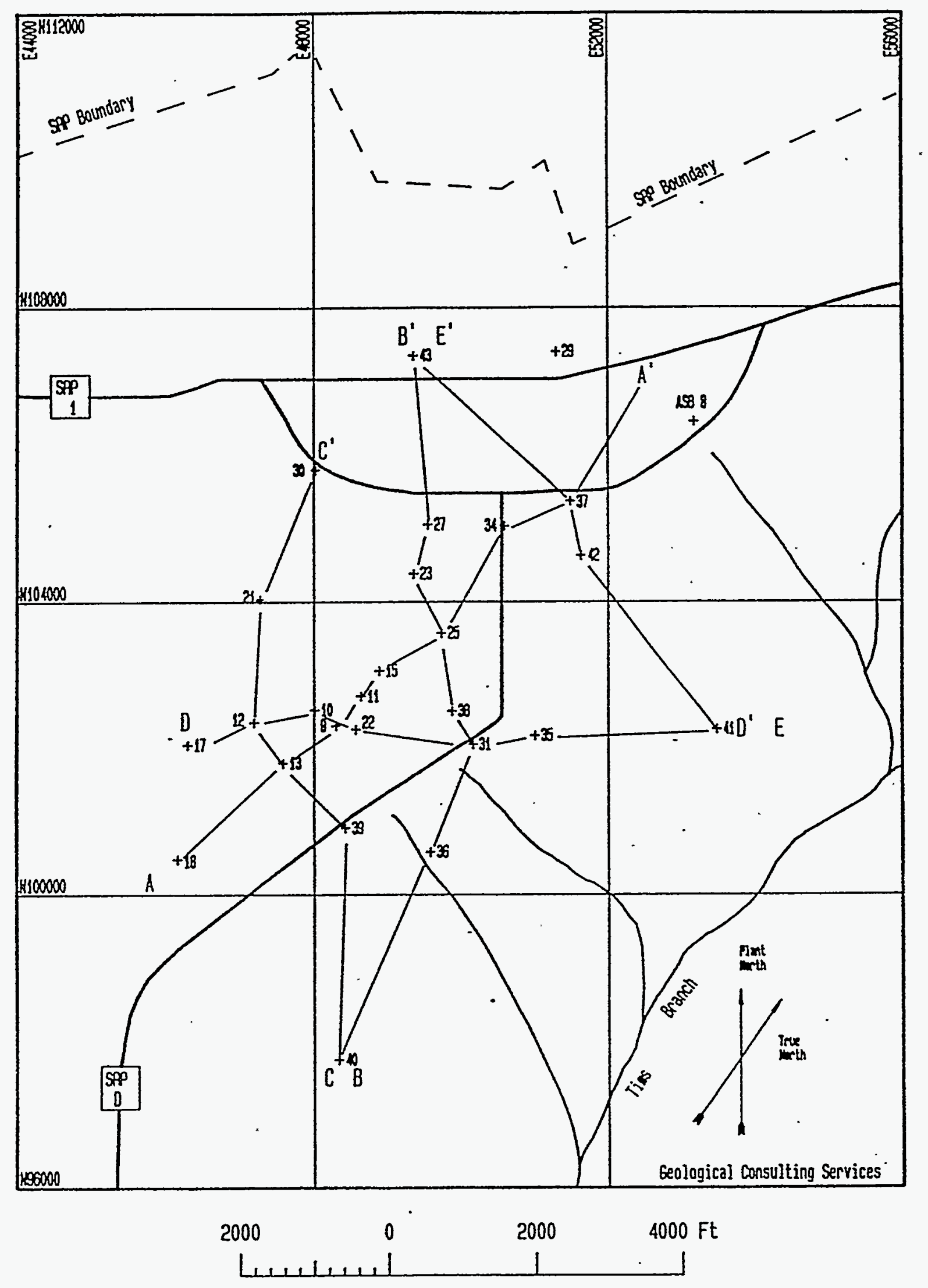

Figure 29. Location map for the cross-sections in Figures 30-34. 


\section{REFERENCES CITED}

Carter, J.G. (ed.), 1983, Biostratigraphy newsletter, Gulf and Atlantic coasts of North America, correlation chart; Chapel Hill, N.C.

Colquhoun, D.J., Woolen, I.D., Van Nieuwenhuise, D.S., Padgett, G.G., Oldham, R.H., Roylan, D.C., Bishop, J.W., and Howel1, P.D., 1983, Surface and subsurface stratigraphy, structure and aquifers of the South Carolina Coastal Plain: South Carolina Department of Health and Environmental Control, Governor's Office, and University of South Carolina, Columbia, S.C., 78 p.

Cooke, C.W., 1936, Geology of the Coastal Plain of South Carolina: U.S. Geological Survey Bullet in 867, $196 \mathrm{p}$.

Fo7k, R.L., and Ward, W.C., 1957, Brazos River bar: a study in the significance of grain size parameters: Journal of Sedimentary Petrology, y. 27, p. 3-27.

ilystrom, P.G., and Willoughby, R.H., (eds.) 1982, Geological Investigations Related to the Stratigraphy in the Kaolin Mining District, Aiken County, South Carolina: Carolina Geological Society Field Trip Guidebook, 1982, South Carolina Geological Survey, Columbia, S.C., p. 80-113.

Siple, G.E., 1967, Geology and ground water of the Savannah River Plant and vicinity South Carolina: U.S. Geological Survey Water-Supply Paper 1841, 173 p.

Sloan, E., 1908, Catalogue of the mineral localities of South Carolina: South Carolina Geological Survey, series IV, Bulletin 2, The State Co., Columbia, S.C. Reprinted by South Carolina Geological Survey, Columbia, S.C., 1979, 506 p.

Steele, K.B., 1985, Lithostratigraphic correlation of Cretaceous and younger-strata of the Atlantic Coastal Plain Province within Aiken Allendale, and Barnwell Counties, South Carolina: Unpublished M.S. Thesis, University of South Carolina, Columbia, S.C., 174 p.

Terry, R.D., and Chilingar, G.V., 1955, Summary of "Concerning some additional aids $i$ studying sedimentary formations" by M.S. Shvetsou: Jour Sedimentary Petrology, v. 25, p. 229-234. 